\title{
Terveysalan pohjoismainen yhteistyö tulevaisuudessa
}

\section{Bo Könberg}

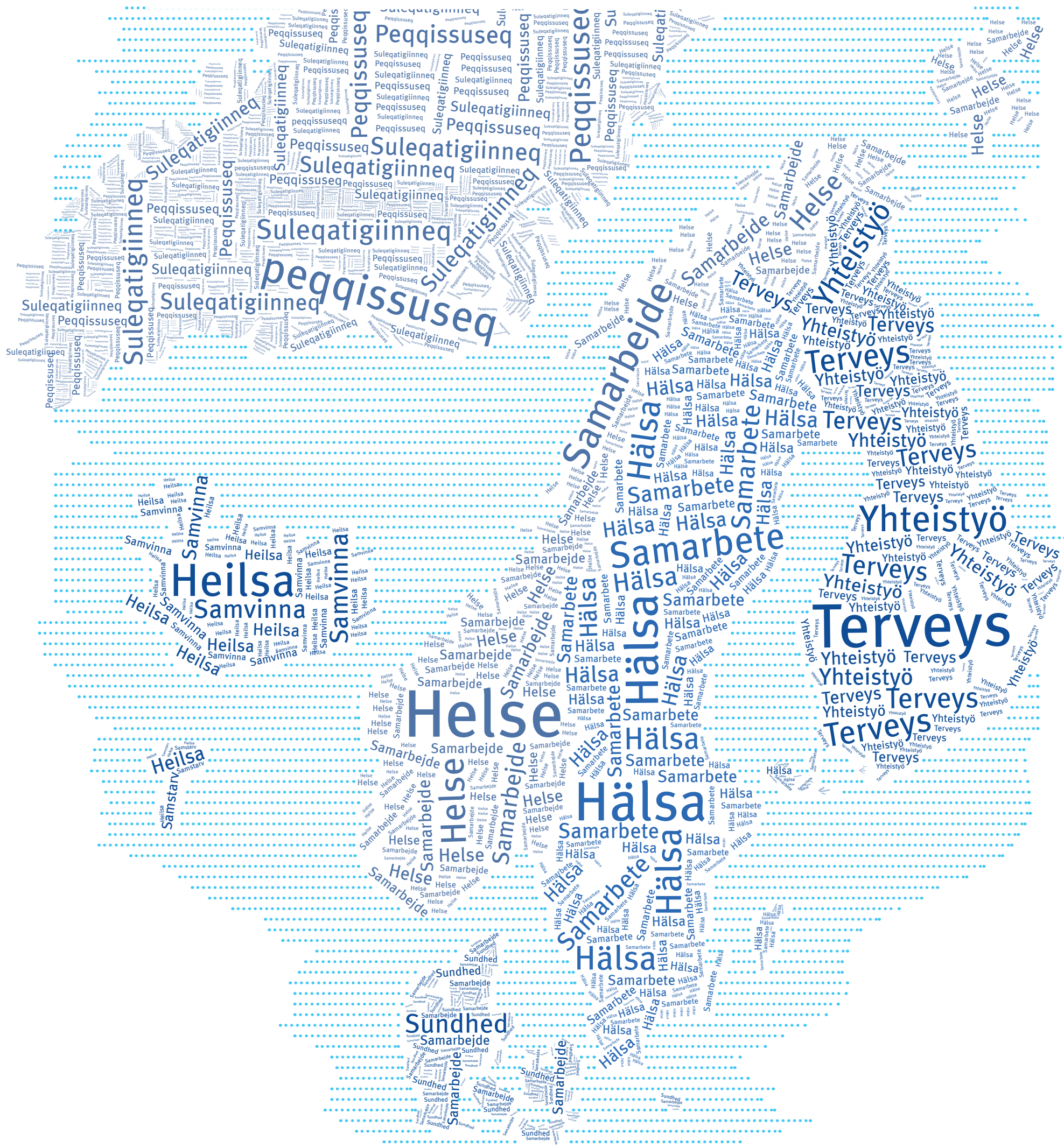




\section{Terveysalan pohjoismainen yhteistyö tulevaisuudessa}

ISBN 978-92-893-2812-8

http://dx.doi.org/10.6027/ANP2014-732

ANP2014:732

(C) Pohjoismaiden ministerineuvosto 2014

Layout: Erling Lynder

Pohjoismaiden ministerineuvosto on myöntänyt tukea raportin julkaisemiseen. Raportin sisältö ei välttämättä edusta Pohjoismaiden ministerineuvoston kantaa, näkemyksiä tai suosituksia.

www.norden.org/fi/julkaisut

Pohjoismaiden ministerineuvosto

Ved Stranden 18

DK-1061 København K

Puhelin (+45) 33960200
Pohjoismainen yhteistyö

Pohjoismainen yhteistyö on yksi maailman laajimpia alueellisia yhteistyömuotoja. Yhteistyön piiriin kuuluvat Islanti, Norja, Ruotsi, Suomi ja Tanska sekä Ahvenanmaa, Färsaaret ja Grönlanti.

Pohjoismaista yhteistyötä tehdään politiikan, talouden ja kulttuurin aloilla tärkeänä osana eurooppalaista ja kansainvälistä yhteistyötä. Pohjoismaisen yhteisön tavoitteena on vahva Pohjola vahvassa Euroopassa.

Pohjoismainen yhteistyö pyrkii vahvistamaan pohjoismaisia ja alueellisia etuja ja arvoja globaalissa maailmassa. Maiden yhteiset arvot lujittavat osaltaan Pohjolan asemaa yhtenä maailman innovatiivisimmista ja kilpailukykyisimmistä alueista. 


\section{Terveysalan pohjoismainen yhteistyö tulevaisuudessa}

\section{Bo Könberg}

Johdanto

Mikrobilääkeresistenssi

Ehdotus 1 Käynnistetään tehotoimia mikrobilääkeresistenssin torjumiseksi

Erityistason sairaanhoito

Ehdotus 2 Vahvistetaan erityistason sairaanhoitoa Pohjoismaissa

Harvinaiset sairaudet

Ehdotus 3 Perustetaan harvinaisten sairauksien pohjoismainen verkosto

Rekisteritutkimus

Ehdotus 4 Perustetaan virtuaalinen pohjoismainen rekisteritutkimuksen keskus

Kansanterveys ja terveyden epätasainen jakautuminen

Ehdotus 5 Lisätään yhteistyötä kansanterveyttä parantavissa toimissa

Ehdotus 6 Pohjoismainen kansanterveyspolitiikan foorumi terveyden epätasaisen jakautumisen vähentämiseksi

Potilasliikkuvuus

Ehdotus 7 Potilasliikkuvuus Pohjoismaissa

Terveys ja teknologia

Ehdotus 8 Lisätään yhteistyötä hyvinvointiteknologian alalla

Ehdotus 9 Lisätään yhteistyötä eTerveyden alalla

Psykiatria

Ehdotus 10 Vahvistetaan pohjoismaista psykiatrian alan yhteistyötä

Terveydenhuollon valmius

Ehdotus 11 Laajennetaan terveydenhuollon valmiusyhteistyön toimeksiantoa

Lääkkeet

Ehdotus 12 Laajennetaan pohjoismaista lääkealan yhteistyötä paremman kustannustehokkuuden ja turvallisuuden saamiseksi

Virkamiesvaihto

Ehdotus 13 Uusi pohjoismainen virkamiesvaihto - pilottihanke

Kansalliset asiantuntijat EU:ssa

Ehdotus 14 Pohjoismaista yhteistyötä kansallisten asiantuntijoiden sijoittamisessa Euroopan komissioon 


\section{Johdanto}

Elokuun 2013 lopussa Pohjoismaiden ministerineuvoston pääsihteeri ja Pohjoismaiden sosiaali- ja terveysministerit tiedustelivat, voisinko laatia raportin pohjoismaisen terveydenhuoltoalan yhteistyön vahvistamisesta. Tarkoituksena oli, että ehdotukset voitaisiin toteuttaa 5-10 vuoden kuluessa. Raportin muodon ja laajuuden osalta esikuvaksi asetettiin pohjoismaista ulko- ja turvallisuuspolitiikkaa käsittelevä arvostettu raportti, jonka Torvald Stoltenberg esitteli Oslossa helmikuussa 2009.

Ministerit nimesivät prosessin kuluessa kaksi yhteyshenkilöä kustakin maasta. Yhteyshenkilöinä toimivat: Flemming Møller Mortensen ja Sophie Løhde Tanskasta, Ulla-Maija Rajakangas ja Anne Louhelainen Suomesta, Unnur Brá Konrádsdóttir ja Árni Páll Árnason Islannista, Cecilie Brein-Karlsen ja Torgeir Micaelsen Norjasta, Lena Furmark ja Lena Hallengren Ruotsista. Olen saanut yhteyshenkilöiltä arvokkaita näkemyksiä, mutta raportissa esitetyistä 14 ehdotuksesta olen yksin vastuussa.

Pohjoismaiden ministerineuvoston vanhempi erityisasiantuntija Astrid Utterström on avustanut minua koko ajan yhteydenpidossa ja raportin laatimisessa.

Olen ollut yhteydessä myös Thorvald Stoltenbergiin ja Sverre Jervelliin, joka oli yksi häntä avustaneista sihteereistä.

Raporttia työstäessäni olen käynyt kaksi kertaa kunkin Pohjoismaan pääkaupungissa sekä kerran Ahvenanmaalla ja Färsaarilla. Grönlannin terveysministerin tapasin Färsaarilla. Yhteensä kokouksia pidettiin yli 80 ja niihin osallistui kaikkiaan noin 250 henkilöä.
Pohjoismaisen yhteistyön lisääminen terveydenhuoltoalalla on herättänyt huomattavaa kiinnostusta, ja minulle on ollut suurta apua kokouksissa sekä muissa yhteyksissä saaduista näkemyksistä.

Pohjoismaiden terveystilanne on hyvä. Keskimääräinen elinikä Pohjoismaissa on yli 80 vuotta, ja kaikki viisi maata ovat 25-26 pisimmän elinajanodotteen maan joukossa ja kolme niistä on 10 pisimmän elinajanodotteen maan ryhmässä. Nopeasti pitenevä elinikä näyttää lisäksi koostuvan terveistä vuosista. Imeväiskuolleisuus on maailman alhaisimpia: kaikki viisi Pohjoismaata ovat 20 parhaan joukossa ja neljä kuuluu niiden 5-6 maan joukkoon, jossa imeväiskuolleisuus on kaikkein alhaisinta.

Alla on joitakin kokousten ja muun yhteydenpidon pohjalta syntyneitä päävaikutelmia:

- Kaikki Pohjoismaat haluavat laajentaa ja vahvistaa terveysalan yhteistyötä.

- Vallitsevan käsityksen mukaan mikrobilääkeresistenssin leviäminen vaatii tehokkaita toimia maailmalla.

- Maat ovat osoittaneet suurta kiinnostusta yhteistyön lisäämiseen erityistason sairaanhoidossa.

- Vallitsevan käsityksen mukaan maiden tulee lisätä ja parantaa rekisteritutkimuksen alalla tehtävää yhteistyötä.

- Mielenterveysongelmat näyttävät lisääntyneen Pohjoismaissa, varsinkin lasten ja nuorten parissa.

- Maat ovat osoittaneet suurta kiinnostusta terveyden epätasaista jakautumista koskevan yhteistyön jatkamiseen ja lisäämiseen. 
Yllä esitettyjen vaikutelmien lisäksi haluan tuoda esiin kaksi tärkeää kysymystä: mikrobilääkeresistenssin ja potilasliikkuvuuden. Jo selvityksen varhaisessa vaiheessa kävi ilmi, että mikrobilääkeresistenssi on lisääntynyt huolestuttavasti maailmalla johtuen antibioottien liiallisesta ja väärästä käytöstä. Työn myötä huoleni on vain lisääntynyt, ja sitä vahvisti entisestään Maailman terveysjärjestön WHO:n runsas kuukausi sitten esittelemä ensimmäinen globaali raportti. Lisävahvistusta antoi vielä mikrobilääkeresistenssiä käsittelevän EU:n ja USA:n yhteisen työryhmän (TATFAR) pari viikkoa myöhemmin esittelemä raportti.

Mikrobilääkeresistenssistä on tulossa yhä isompi ongelma maailmalla. Bakteereista on tullut vastustuskykyisiä erityyppisille antibiooteille ja lisäksi lääkkeille vastustuskykyisen tuberkuloosin ja malarian esiintyminen on erittäin huolestuttavaa. Tuberkuloosi- ja malariakuolleisuutta on pystytty vähentämään viime vuosikym. meninä tehokkaiden lääkkeiden ansiosta, mutta nyt resistentit ja monilääkeresistentit tuberkuloosibakteerit ovat alkaneet lisääntyä hälyttävästi.

Antibioottien sekä tuberkuloosi- ja malarialääkkeiden huolestuttava tilanne antaa mielestäni aihetta käsitellä kysymystä pohjoismaisessa ministerikokouksessa syksyllä.

Potilasliikkuvuudessa on kysymys Pohjoismaiden kansalaisten oikeudesta saada hoitoa toisessa maassa. EU:n jäsenmaissa sekä Norjassa ja Islannissa asian käsittely etenee EU:n potilasliikkuvuusdirektiivin puitteissa. Pohjoismaat tekivät äskettäin päätöksen direktiivin täytäntöönpanosta. Kokemuksia direktiivin vaikutuksista Pohjoismaiden kansalaisille ei luonnollisesti vielä ole saatavilla.

Odottaessamme tarkempaa tietoa Pohjoismaiden uusien ja osittain keskenään erilaisten sääntöjen vaikutuksesta potilasliikkuvuuteen en esitä nyt lisäparannuksia, vaan ehdotan, että asiaa käsitellään ministerikokouksessa ensi vuonna.

Keskeinen asia on tietenkin se, mitä terveydenhuollon kysymyksiä voidaan hoitaa paremmin pohjoismaisen yhteistyön avulla. Tässä yhteydessä tulee arvioida myös sitä, mitä asioita pystytään hoitamaan vielä paremmin Euroopan tasolla.

Kokousten ja muun yhteydenpidon pohjalta olen laatinut 14 konkreettista ehdotusta. Ne on muotoiltu siten, että kaikki Pohjoismaat voivat osallistua työhön. Sekin on mahdollista, että 3-4 maata jatkaa yhteistyötä pidemmälle ja muut maat voivat tulla mukaan myöhemmin tai jättää osallistumatta.

Reykjavikissa 11. kesäkuuta 2014

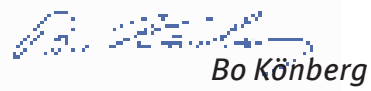




\section{Mikrobilääkeresistenssi}

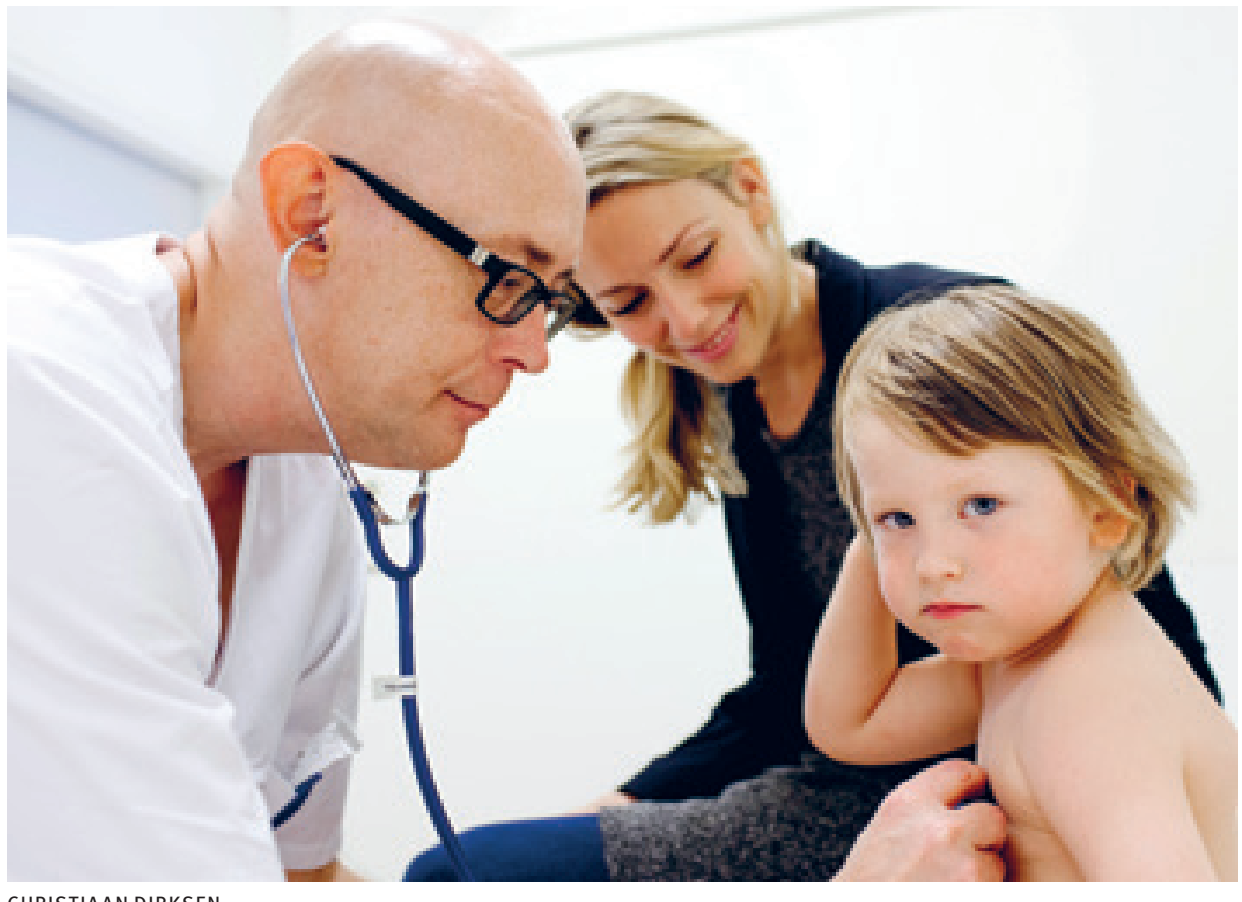

\section{Ehdotus 1}

\section{Käynnistetään tehotoimia mikrobilääkeresistenssin torjumiseksi}

Pohjoismaat edistävät määrätietoisesti tehokkaita toimia lisääntyvän mikrobilääkeresistenssin ja lääkkeille vastustuskykyisen tuberkuloosin ja malarian torjumiseksi. Vaikka Pohjoismaissa käytetään muuhun Eurooppaan verrattuna keskimäärin vähemmän antibiootteja ja vaikka maat itse ovat vain pieneltä osin syyllisiä tähän maailmanlaajuiseen ongelmaan, niiden on otettava tavoitteekseen vähentää nopeasti, mieluiten tulevien viiden vuoden aikana, antibioottien kulutusta Euroopan alimmalle tasolle, joka on tällä hetkellä Alankomaissa.

Pohjoismaat tukevat myös antibioottien liikakäyttöä torjuvan ohjelman nopeaa toteuttamista EU:n, WHO:n, ja YK:n puitteissa. Näin voidaan vahvistaa järjestelmiä ja yhteistyörakenteita uusien antibioottien kehittämiseksi ja palkita uusien antibioottien kehittelytyötä. Ohjelman tulee sisältää kolme kohtaa:
- Reseptipakon käyttöönotto niissä maissa, joiden terveydenhuoltojärjestelmä sallii sen, ja bonusten maksamisen lopettaminen antibiootteja määrääville lääkäreille ja sairaaloille. Myöskään eläinlääkärit eivät saisi enää myydä itse määräämiään antibiootteja. 
- Kaikkien maiden tulee ottaa käyttöön sääntöjä ja tavoitteita oman käytön vähentämiseksi.

- Lisätään kannustimia uusien antibioottien kehittämiseksi. Rikkaiden maiden tulee antaa reilut puolitoista miljardia euroa vuosittain seuraavien viiden vuoden aikana vahvistaakseen järjestelmiä ja yhteistyörakenteita, joilla voidaan edistää uusien antibioottien kehittämistä, ja palkitakseen uusien lääkkeiden keksijöitä ja kehittäjiä.

Yksi 1900-luvun suurimmista keksinnöistä on penisilliinin ja muiden ihmiskehon bakteereja tuhoavien antibioottien keksiminen ja teollinen valmistaminen. Keksintö tehtiin runsaat 80 vuotta sitten, ja vuonna 1945 keksinnölle myönnettiin lääketieteen Nobelin palkinto. Yksi palkinnonsaajista, Sir Alexander Fleming, varoitti kiitospuheessaan siitä, että liikakäyttö voisi tulevaisuudessa heikentää antibioottien tehoa.

Liikakäyttöä ja siitä aiheutuvaa vastustuskykyä antibiooteille on esiintynyt jo kauan. Euroopassa kuoli viime vuonna ainakin 25000 ihmistä mikrobilääkeresistenssin yleistymisen takia. Liikenteessä kuolleiden määrä Euroopassa samana vuonna oli saman verran. Yhdysvalloissa vastaavaksi luvuksi arvioitiin vähän aikaa sitten yli 23000 ihmistä. Tämän lisäksi uusien antibioottien keksiminen on käytännössä loppunut. Vuoteen 1970 mennessä kehitettiin parikymmentä uutta antibioottia. Sen jälkeen on tullut kaksi uutta antibioottia, kumpikin ennen vuotta 1987 !

Uusia keksintöjä ei ilmeisesti ole lähiaikoina odotettavissa. Viimeisimmän tiedon mukaan uusia antibiootteja ei ole kehitteillä, ja nykyisellä kehityksellä uusia lääkkeitä ei todennäköisesti ole tulossakaan lähimpien kymmenen vuoden aikana!

Mikrobilääkeresistenssi aiheuttaa isoja ongelmia sairaanhoidossa, koska nykyaikainen sairaanhoito on täysin riippuvainen antibiooteista. Lisääntyvä in- fektiokuolleisuus on suuntaus, joka näkyy entistä selvempänä tulevaisuudessa. Tämä koskee haavoista tai liikenneonnettomuuksista seuranneita infektioita ja aivan tavallisia infektiotauteja, kuten keuhkokuumetta tai virtsatietulehdusta, joita yleensä pidetään vaarattomina, koska ne ovat hoidettavissa antibiooteilla. Monet elinsiirrot ja leikkaukset ovat tulevaisuudessa mahdottomia tai erittäin vaarallisia, koska leikkausten yhteydessä annetaan antibiootteja sekä ennaltaehkäisynä että toimenpiteen jälkeen. Puolustuskykyä heikentävissä sairauksissa kuten syövässä tai HIV:ssä kuolinsyynä on usein parantumaton infektio.

Tämä erittäin huolestuttava kehitys pantiin merkille muun muassa WHO:ssa runsaat 10 vuotta sitten, mutta lähimainkaan riittäviin toimenpiteisiin ei ole ryhdytty. Huhtikuun lopussa WHO esitteli ensimmäisen globaalin raporttinsa mikrobilääkeresistenssin sekä lääkeresistentin tuberkuloosin ja malarian yleistymisestä. Raportin sisältö on erittäin hälyttävä. Pari viikkoa myöhemmin EU:n ja USA:n transatlanttinen erityistyöryhmä (TATFAR) esitteli myös raportin huolestuttavasta kehityksestä.

Mikrobilääkeresistenssin lisäksi kehitys on huolestuttavaa myös lääkeresistentin tuberkuloosin ja malarian kohdalla. Tuberkuloosin ja malarian aiheuttama kuolleisuus on vähentynyt viime vuosikymmeninä tehokkaiden lääkkeiden ansiosta, mutta nyt vastustuskyky on lisääntynyt nopeasti myös näille lääkkeille.

Kaikille pitäisi olla selvää, että tarvitaan erityisen nopeita toimia käytön vähentämiseksi, jotta saamme lisäaikaa uusien antibioottien kehittämiseen. Tämän työn vauhdittamiseksi tarvitaan myös vahvoja taloudellisia kannustimia.

Liikakäyttö on hyvin todennäköisesti vähäisempää Pohjoismaissa ja muualla Euroopassa kuin Kiinassa, Intiassa ja Yhdysvalloissa, mutta sitä on tietysti edelleen vähennettävä - jotta resistenssin kasvunopeus hidastuisi ja jotta muuta maailmaa saataisiin vähentämään kulutustaan. 
Tavallinen tapa mitata lääkekulutusta on vuorokausiannoksen määrä tuhatta asukasta kohti. Kaaviosta käy ilmi, että Euroopan maiden väliset erot ovat hyvin suuret - Turkin 42:sta Alankomaiden 11:een. Suurimman kulutuksen maa Euroopassa käyttää siis 3,5 kertaa enemmän antibiootteja kuin alhaisimman kulutuksen maa!
Suurimmassa osassa Pohjoismaista kulutus on Euroopan keskiarvon alapuolella; Ruotsi on lähes Alankomaiden tasolla. Kuitenkin ero Ruotsin ja korkeinta kulutustasoa Pohjoismaissa edustavan Islannin välillä on jopa reilut $50 \%$.

\section{Antibioottien käyttö 2011 sairaaloiden ulkopuolella}

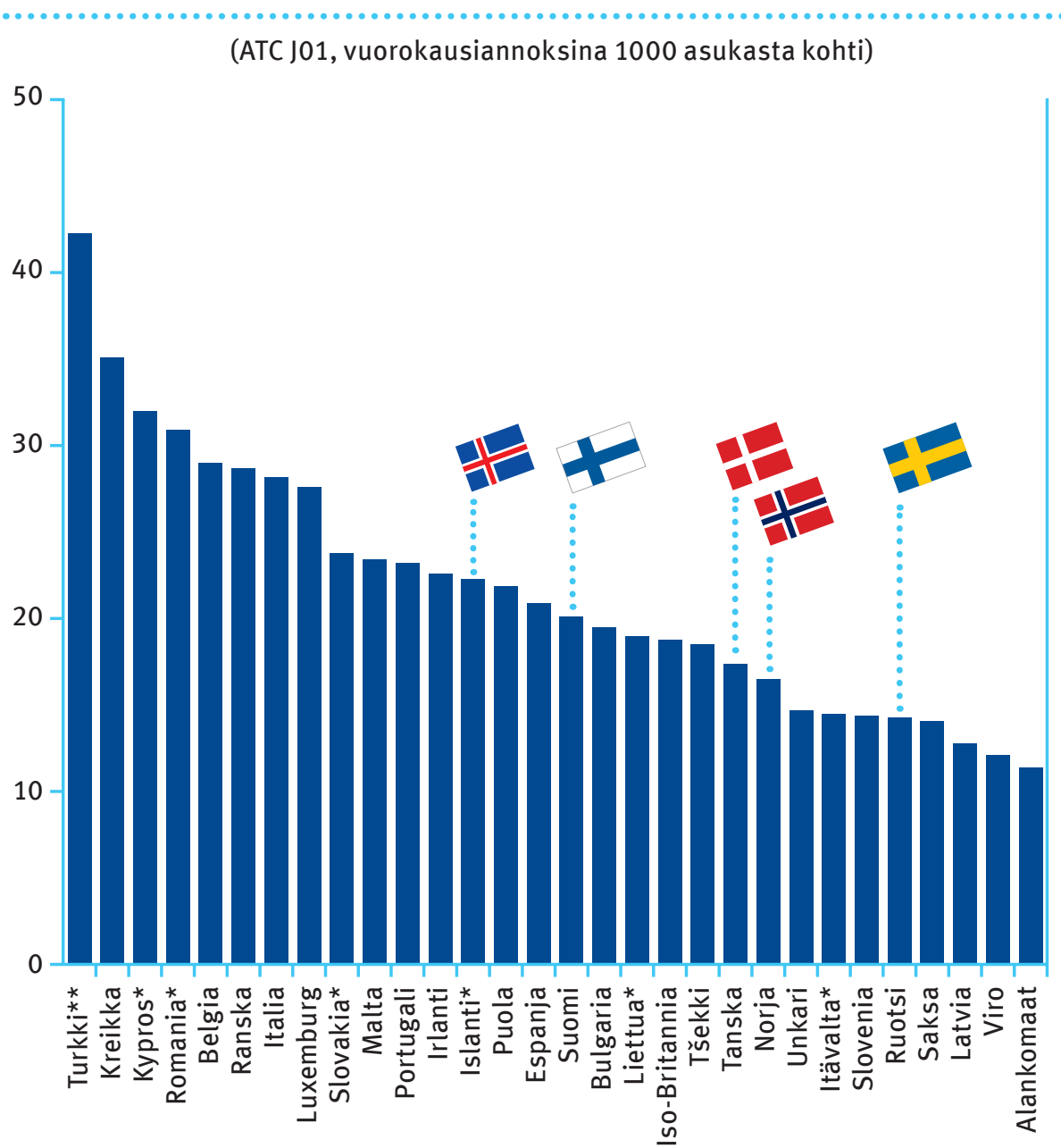

Lähde: European Centre for Disease Prevention and Control (ECDC), Consumption of antimicrobials of Antibacterials For Systemic Use (ATC group J01) in the community (primary care sector) in Europe, reporting year 2011

* ECDC-huomautus: Luku ilmoittaa kokonaiskulutuksen mukaan lukien sairaalakulutuksen.

**Lähde: The Lancet Infectious Disease, Vol 14 May 2014, Antibiotic use in eastern Europe: a crossnational database study in coordination with the WHO Regional Office for Europe. Luku ilmoittaa kokonaiskulutuksen mukaan lukien sairaalakulutuksen. 
Kohtuullinen tavoite Pohjoismaita ajatellen olisi vähentää kulutusta viiden vuoden aikana Alankomaiden nykyiselle tasolle.

Monet maat, Turkki mukaan lukien, ovat laatineet suunnitelmia vähentääkseen antibioottien liikakäyttöä. Toinen esimerkki on Intia, joka hyväksyi vuonna 2012 mikrobilääkeresistenssin torjumista koskevan viisivuotissuunnitelman, niin kutsutun Chennain julistuksen.

Ihmisten lisäksi antibiootteja käytetään paljon myös kotieläimillä. Antibiootteja käytetään bakteeri-infektioihin, mutta myös kaupallisista syistä lisäämään eläin ten lihaskasvua. EU:ssa viimeksi mainittu ei enää ole sallittua, mutta käyttö ennalta ehkäisevässä tarkoituksessa on sallittua ja rajat ovat jokseenkin epämääräiset. Ruotsi on esimerkki onnistuneesta mikrobilääkkeiden käytön vähentämisestä eläimillä. Ruotsissa antibioottien käyttö eläimillä on kuluneiden kuuden vuoden aikana vähentynyt yli kolmanneksella tasolle, joka on luultavasti EU:n alhaisin. Tähän on päästy parantamalla eläinten hoitoa ja hygieniaa. Kulutus on vieläkin alhaisempaa Islannissa ja Norjassa.

Vaikka EU:ssa on yhteiset säännöt mikrobilääkkeiden antamisesta eläimille, maiden välillä on edelleen isoja eroja. Joissakin EU:n jäsenvaltioissa eläinlääkärit voivat itse myydä määräämänsä antibiootit. Tämän seurauksena lääkemääräyksiä saatetaan kirjoittaa useammin ja liikaa, mille on tehtävä loppu. EU:ssa on otettava käyttöön kielto, joka estää eläinlääkäreitä ansaitsemasta rahaa antibioottien myynnillä.

EU-maiden väliset erot myös kotieläintaloudessa käytettävien antibioottien määrässä ovat erittäin isot. Eräänäkin vuonna jotkut maat käyttivät antibiootteja lihakiloa kohti 30 kertaa enemmän kuin pienimmän kulutuksen maa Ruotsi.

Myönteinen esimerkki tältä vuodelta on se, että Pohjoismaiden ministerineuvosto on tehnyt aloitteen One Health -näkökulman sisällyttämisestä pohjoismaiseen yhteis- työhön perustamalla uuden työryhmän käsittelemään mikrobilääkeresistenssiä.

Välittömiä toimia, joihin Pohjoismaiden tulee ryhtyä, ovat muun muassa sairaanhoidon rutiinien ja hygienian parantaminen sekä edellä mainitun 5-vuotistavoitteen asettaminen sairaanhoidossa käytettävien mikrobilääkkeiden vähentämiseksi Alankomaiden nykyiselle tasolle.

EU:ssa, WHO:ssa ja YK:ssa on työskenneltävä aktiivisesti mikrobilääkkeiden liikakäytön vähentämistä ihmisillä ja eläimillä koskevien tavoitteiden asettamiseksi kaikille maille ja tehokkaiden taloudellisten kannustimien saamiseksi uusien mikrobilääkkeiden kehitystyölle. Pohjoismaiden täytyy toimia edelläkävijänä tässä asiassa.

Myös Pohjoismaiden kehitysmaille antamassa kehitysavussa on otettava esille kysymys mikrobilääkkeiden liikakäytöstä.

EU:Ssa on viime vuosina pyritty kannustamaan mikrobilääkealan innovointiin taloudellisilla keinoilla ja muulla tavoin. Toimet eivät kuitenkaan ole riittäviä.

Uusien mikrobilääkkeiden kehittämisessä vaikuttaa olevan huomattavia tieteellisiä ongelmia. Suuri syy siihen, ettei uusia mikrobilääkkeitä kehitetä, on todennäköises ti nykyisten taloudellisten kannustimien heikkous, koska uusia lääkkeitä on tarkoitus käyttää harvoin ja siten niistä saataisiin vähemmän tuloja kuin usein käytettävistä lääkkeistä.

Uusien mikrobilääkkeiden kehittämiseen liittyvän ongelman ratkaisemiseksi tarvitaan mitä todennäköisimmin miljardeja euroja. Nämä varat on saatava rikkailta mailta. Ehdotankin sen vuoksi, että EU, USA ja muut rikkaat maat sopivat, että ne tulevien viiden vuoden aikana varaavat vuosittain noin 0,05 promillea bruttokansantuotteestaan uusien mikrobilääkkeiden kehittämiseen ja kehittäjien palkitsemiseen. Samalla maat saisivat uusien lääkkeiden omistusoikeuden ja pystyisivät siten 
määräämään ehdot uusien lääkkeiden käytölle.

Pohjoismaille tämä merkitsee noin 55 miljoonaa euroa vuosittain ja EU:Ile, USA:Ile sekä muille rikkaille maille reilut puolitoista miljardia euroa, mistä kertyisi viidessä vuodessa runsaat kahdeksan miljardia euroa. Myöhemmin voidaan päättää, kuinka suuri osa tästä käytetään tutkimukseen ja kuinka suuri osa uusien lääkkeiden kehittäjien palkitsemiseen.

Edellä esitetyn perusteella ehdotetaan, että asia otetaan käsiteltäväksi ministerikokouksessa syksyllä 2014. 


\title{
Erityistason sairaanhoito
}

\section{Ehdotus 2 - Vahvistetaan erityistason sairaanhoitoa Pohjoismaissa}

\author{
Perustetaan pohjoismainen korkean tason valmisteluryh- \\ mä tukemaan ja kehittämään erityistason sairaanhoitoa \\ Pohjoismaissa.
}

Pohjoismailla on monia yhteisiä piirteitä ja sen vuoksi erityistason sairaanhoitoa koskeva yhteistyö on luonnollinen valinta. Parhaillaan Pohjoismaiden terveydenhuollossa on meneillään voimakas keskittäminen. Kielellisten ja kulttuuristen yhtäläisyyksien lisäksi Pohjoismaissa on myös suhteellisen pienet väestömäärät ja sairausmallit sekä kliiniset käytännöt muistuttavat toisiaan.

Sen vuoksi Pohjoismaat tekevät jo nyt hyvää yhteistyötä erityistason sairaanhoidossa. Työtä on kuitenkin vahvistettava ja kehitettävä siten, että yhteistyön kautta voidaan paremmin hyödyntää nykyisiä mahdollisuuksia lisätä tehokkuutta ja parantaa laatua sekä käyttää maiden taloudellisia resursseja järkevästi.

Yhteistyön vahvistamiseksi ja jotta saataisiin tuettua maiden strategisia arvioita pohjoismaisen yhteistyön mahdollisuuksista, on perustettava pohjoismainen korkean tason valmisteluryhmä. Valmisteluryhmän tehtävänä on tukea maita niiden arvioidessa säännöllisesti, milloin pohjoismaisesta yhteistyöstä voi olla hyötyä konkreettisessa erityistason hoidossa, esimerkiksi tekemällä yhteistyötä kalliiden teknisten laitteiden hankinnassa sekä helpottamalla uusien yhteistyöaloitteiden käynnistämistä.

Valmisteluryhmän pääasiallisena tehtävänä on tarjota maille foorumi säännöllisille keskusteluille alan yhteistyöaloitteiden tarpeista ja mahdollisuuksista. Kunkin maan tulee ilmoittaa valmisteluryhmälle, kun uusi erityistason hoitopanostus on suunnitteilla. Valmisteluryhmä voi siten pohtia, olisiko pohjoismaisesta yhteistyöstä hyötyä kyseisen panostuksen yhteydessä, jos vastaavia tarpeita tai kokemusta aiheesta löytyy yhdestä tai useammasta Pohjoismaasta. Kukin maa vie asian valmisteluryhmään niin varhaisessa vaiheessa, että pohjoismaista yhteistyötä voidaan tarvittaessa käynnistää. Lainsäädännölliset esteet pohjoismaisen yhteistyön lisäämiselle poistetaan.

Valmisteluryhmän tulee pohtia relevantteja yhteistyöaloitteita koskevien keskustelujen yhteydessä, onko aloitteiden toteuttamiselle edellytyksiä. Esimerkiksi jatkuvasti on selvitettävä, mitä lainsäädännöllisiä esteitä on ratkaistava pohjan luomiseksi tehokkaalle pohjoismaiselle yhteistyölle erityistason sairaanhoidossa. Valmisteluryhmän tulee keskustella säännöllisesti myös siitä, miten maat ymmärtävät erityistason sairaanhoidon. Valmisteluryhmän työ perustuu kokemuksille, joita on saatu jo käynnissä olevasta pohjoismaisesta yhteistyöstä, muun muassa Pohjoismaiden ministerineuvoston Kestävä pohjoismainen hyvinvointi -ohjelmassa toteutettavasta erityistason sairaanhoidon aloitteesta.

Yhteistyöpäätökset tulee sisällyttää laajemmin uusia aloitteita koskevaan strategiseen suunnitteluun maissa ja kytkeä ne läheisesti poliittiseen päätöksentekoon. Valmisteluryhmän jäsenten tulee sen 
vuoksi olla riittävän korkean tason edustajia. Valmisteluryhmällä tulee olla kytkentä pohjoismaiseen sosiaali- ja terveyspoli- tiikan ministerineuvostoon, jolta ryhmä myös saa toimeksiantonsa. 


\section{Harvinaiset sairaudet}

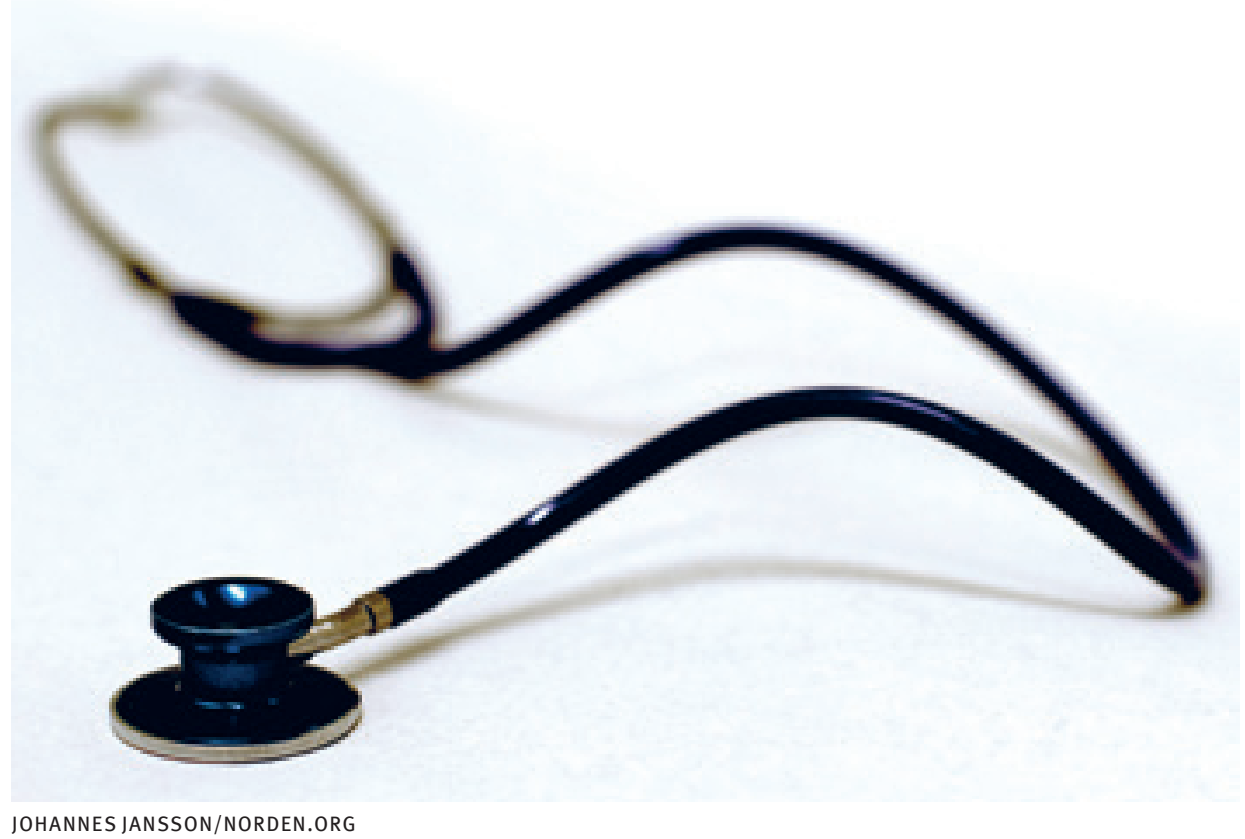

\section{Ehdotus $3 \quad$ Perustetaan harvinaisten sairauksien pohjoismainen verkosto}

\section{Perustetaan harvinaisiin sairauksiin keskittyvä pohjoismainen verkosto.}

Pohjoismaiden väestömäärät ovat suhteellisen pienet ja haasteena onkin saada riittävän suuri väestöpohja harvinaisia sairauksia koskevissa panostuksissa tarvittavan osaamisen kehittämiseksi ja ylläpitämiseksi. Pohjoismaissa on kuitenkin yhteensä noin 26 miljoonaa asukasta ja maiden yhteisistä piirteistä johtuen on luonnollista tehdä yhteistyötä, joka vahvistaa yksittäisten maiden osaamisympäristöjä ja panostuksia harvinaisten sairauksien alalla.

Pohjoismaat ovat usean vuoden aikana käynnistäneet erityyppistä yhteistyötä harvinaisten sairauksien alalla, esimer- kiksi tiedonvaihtoa Rarelink-linkkisivuston avulla. Näitä yhteistyömuotoja tulee kehittää, mutta tärkeää on myös vahvistaa käynnissä olevia ja uusia Pohjoismaiden yhteisiä panostuksia sekä parantaa niiden koordinointia.

Maiden tulee sen vuoksi perustaa pohjoismainen verkosto edistämään harvinaisia sairauksia koskevaa yhteistyötä ja turvaamaan työssä tarvittava jatkuvuus. Siten alan pohjoismaisella yhteistyöllä on enemmän vaikutusta asianomaisiin toimintaympäristöihin ja maiden viranomaisiin sekä lopulta myös asukkaisiin. 


\title{
Rekisteritutkimus
}

\section{Ehdotus 4 Perustetaan virtuaalinen pohjoismainen rekisteritutkimuksen keskus}

\author{
Pohjoismaista tutkimusyhteistyötä rekisteritietojen, \\ biopankkien ja kliinisten interventiotutkimusten alalla \\ vahvistetaan edistämällä ainutlaatuisten pohjoismaisten \\ kansallisten rekisterien tutkimuskäyttöä. Pohjoismaisissa \\ tutkimushankkeissa otetaan käyttöön eettisten arviointien \\ keskinäisen hyväksymisen malli. Tällainen yhteistyö tukee \\ tutkimuksen, elinkeinoelämän ja hyvinvoinnin kehittämistä \\ Pohjoismaissa.
}

\begin{abstract}
Pohjoismaat ovat populaatiotutkimuksen kultakaivos johtuen hallinnollisiin rekistereihin ja biopankkeihin kerättyjen yksilötietojen saatavuudesta. Näitä tietoja on kerätty pitkän ajan kuluessa ja ne kattavat usein koko Pohjolan väestön. Pohjoismaiden terveys- ja hyvinvointijärjestelmien samankaltaisuus sekä henkilötunnuksemme ovat hyvä lähtökohta vertailevien tutkimusten ja analyysien tekemiselle Pohjoismaissa. Asukkaita Pohjoismaissa on yhteensä 26 miljoonaa, mikä on riittävä väestöpohja harvinaisten sairauksien tutkimiseen.
\end{abstract}

Kansallisten rekisterien laajemmalla tutkimuskäytöllä voidaan edistää sairauksien ennaltaehkäisyä, tehokkaampien lääkkeiden löytämistä ja hoitomenetelmien kehittämistä esimerkiksi yksilöllisessä sairaanhoidossa. Vahvistamalla alan pohjoismaista yhteistyötä lisätään kliinisiä tutkimuksia ja edistetään siten paremman tietopohjan saamista hyvinvointisektorin poliittisille priorisoinneille sekä parannetaan elinkeinoelämän kilpailukykyä. Samalla Pohjoismaat voisivat vahvistaa brändiään vetovoimaisena huippututkimusalueena.
Seuraavat toimet ovat välttämättömiä, jotta saatavilla olevaa tietoa voidaan käyttää:

Maiden on poistettava käytännölliset, juridiset ja eettiset esteet, jotka haittaavat rekisteritietojen yhteiskäyttöä tutkimuksessa. Kansallisten rekisterinpitäjien, jotka vastaavat muun muassa hallinnollisista henkilörekistereistä ja biologisista rekistereistä (sairaanhoidon laaturekisterit, biopankit), tulee tehdä yhteistyötä tiedon hyödyntämisen ja siirron helpottamiseksi maiden välillä.

Pohjoismaisissa tutkimushankkeissa otetaan käyttöön malli eettisten arviointien keskinäiselle hyväksymiselle.

Maiden tulee lisäksi pyrkiä helpottamaan henkilötietojen käyttöä rajat ylittävässä tutkimuksessa nykyisen lainsäädännön rajoissa esimerkiksi muuttamalla käytäntöjään. Maiden tulee myös selvittää mahdollisia synergiaetuja, varsinkin alan uuden eurooppalaisen lainsäädännön osalta. 
Tutkimusinfrastruktuuria tulee vahvistaa näillä aloilla. NordForskin ja tutkimusneuvostojen (tai vastaavien) tulee tukea teknisten ratkaisujen kehittämistä, jotta henkilötietoja ja tutkimustietoja voidaan turvallisesti siirtää, tallentaa ja käyttää myös rajojen yli. Yksinkertaisemman tietojen koordinoinnin lisäksi tulee mahdollistaa myös yhteispohjoismaisten tietolähteiden ja rekisterien luominen. Lisäksi NordForskin ja tutkimusneuvostojen tulee rahoittaa tutkimusta ja koulutusta Pohjoismaissa yhteispohjoismaisten tietolähteiden hyödyntämiseksi. NordForsk on jo tehnyt valmisteleva toimia.

Kun käytännölliset, juridiset ja eettiset esteet on raivattu, panostuksia tutkimus- infrastruktuuriin ja tutkimukseen tulee kehittää virtuaalisen pohjoismaisen rekisteritutkimuksen keskuksen perustamiseksi. Tällainen keskus mahdollistaisi sen, että tutkijat ja yritykset voisivat käyttää ainutlaatuisia tietorekistereitämme yhteispohjoismaisena resurssina, ja se toimisi myös yhteistyöfoorumina kansallisille toimijoille. Samalla työ jatkuisi rajat ylittävää tutkimusta haittaavien esteiden poistamiseksi. Jaetun yhteispohjoismaisen resurssin koordinointi voisi olla NordForskin tehtävä, esimerkiksi pohjoismaisessa e-infrastruktuuriyhteistyössä (NeIC) noudatettavan mallin mukaan, läheisessä yhteistyössä keskeisten kansallisten toimijoiden kanssa. 


\title{
Kansanterveys ja terveyden epätasainen jakautuminen
}

\section{Ehdotus 5 Lisätään yhteistyötä kansanterveyttä parantavissa toimissa}

\author{
Pohjoismaat lisäävät kokemustenvaihtoa kansanterveysky- \\ symyksissä, varsinkin tupakoinnin ja alkoholin väärinkäy- \\ tön osalta.
}

Tupakka ja alkoholi ovat kaksi sosiaalisesti hyväksyttyä piristettä suurissa osissa maailmaa, vaikka ne heikentävätkin kansanterveyttä. Pohjoismaissa on yleisesti alhaisempi alkoholin ja tupakan kulutus kuin muualla Euroopassa, mutta tupakasta ja alkoholista johtuvien sairauksien vähentämiseksi tehtävä työ voisi olla vielä aktiivisempaa varsinkin syövän osalta. Pohjoismaiden tulee tehdä päätös tiiviimmän kokemusten vaihdon käynnistämisestä kansanterveysalalla, etenkin alkoholi- ja tupakkapolitiikan keinoista.
Pohjoismaiden kansanterveydessä on vie-

lä paljon parantamisen varaa, vaikka elinikä on pidentynyt huomattavasti ja vaikka kyse on terveistä vuosista, kuten raportin alussa mainittiin. Kaksi tärkeintä aluetta, joihin poliittisilla päätöksillä myös voidaan vaikuttaa, ovat tupakointi ja alkoholin väärinkäyttö.

Elinajanodotetta Pohjoismaissa kuvaavan taulukon ja tupakan sekä alkoholin kulutusta esittelevän taulukon vertailu osoittaa asioiden olevan yhteydessä toisiinsa.

\section{Elinajanodote}

(vuosina)

2012

Lisäys (vuosina) 1960-2012*

\begin{tabular}{lcc}
\hline Islanti & 82,9 & 9 \\
Ruotsi & 81,7 & 9 \\
Norja & 81,5 & 8 \\
Suomi & 80,6 & 12 \\
Tanska & 80,1 & 8
\end{tabular}

Pohjoismaat

keskimäärin

81,4

9

Tiedot: Maailmanpankki 2012

*pyöristetty lähimpään kokonaislukuun 


\section{Päivittäin tupakoivat miehet}

(prosentteina 15-vuotiaista ja sitä vanhemmista miehistä)

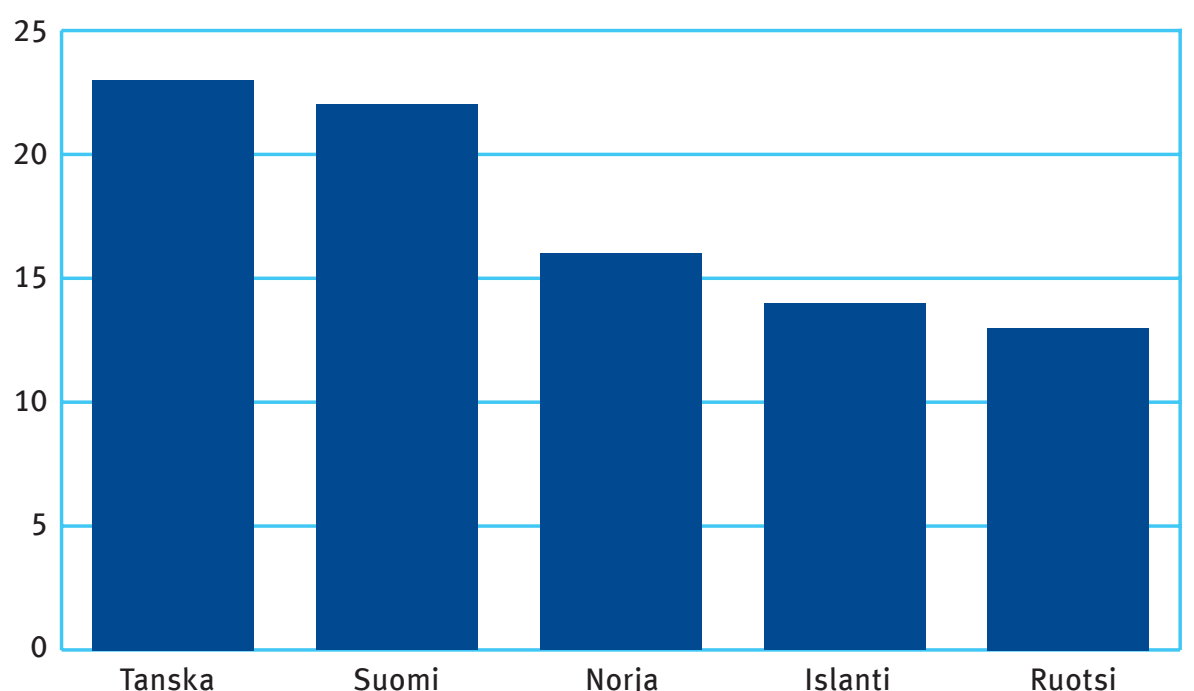

Lähde: Pohjoismaiden terveystilasto 2013 (Nomesko), s. 44, taulukko 3.1.2 Päivittäin tupakoivat prosentteina sukupuolen mukaan

Ikäryhmät: Tanska 16+, Suomi 15-64-vuotiaat, Norja 16-74-vuotiaat, Islanti 15+, Ruotsi 16-84

Alkoholijuomien myynti litroina $100 \%$ puhdasta alkoholia asukasta kohti

(15-vuotiaat ja sitä vanhemmat)

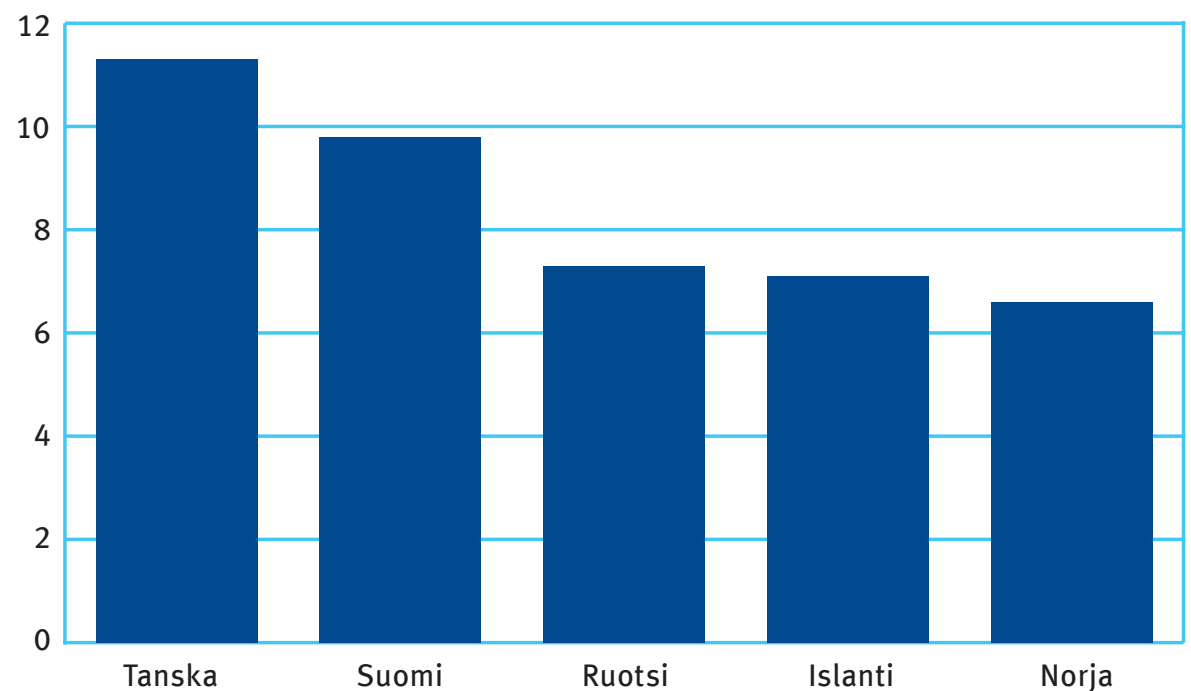

Lähde: Pohjoismaiden terveystilasto 2013 (Nomesko), s. 47, taulukko 3.1.4 Alkoholijuomien myynti litroina $100 \%$ puhdasta alkoholia asukasta kohti (15-vuotiaat ja sitä vanhemmat)

Suomen ja Norjan luvut ovat vuodelta 2011, Tanskan ja Ruotsin vuodelta 2010 ja Islannin vuodelta 2005. 


\section{Itse ilmoitettu liikalihavuus, miehet}

(prosentteina 15-vuotiaista ja sitä vanhemmista)

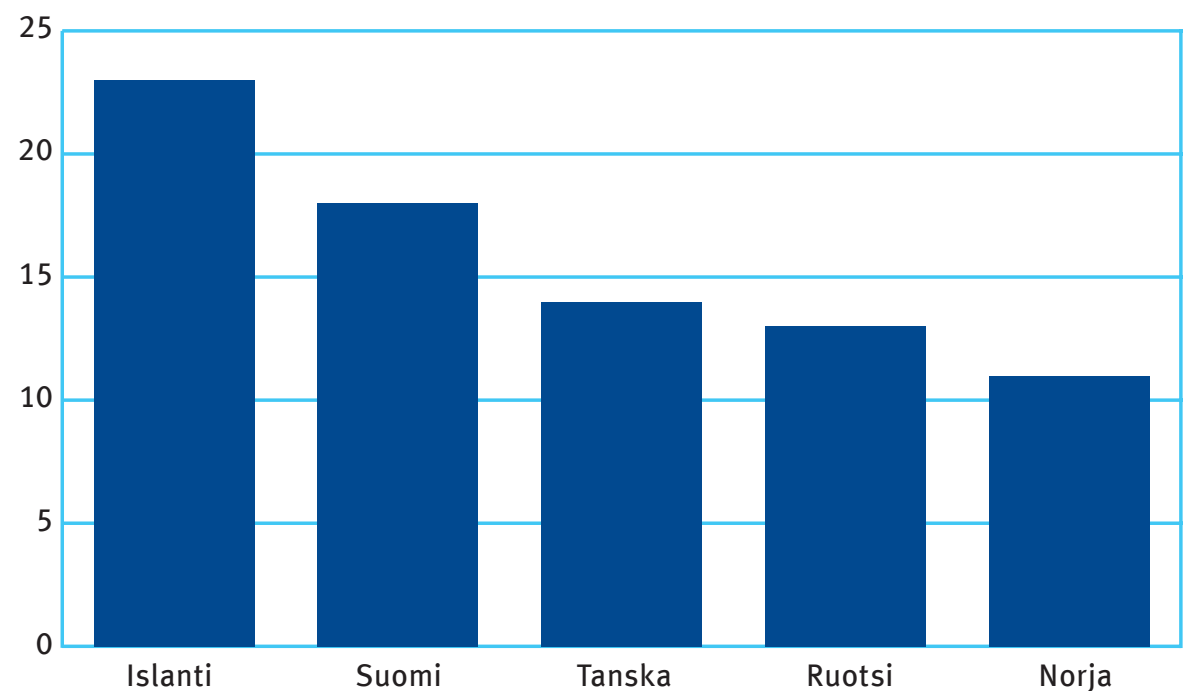

Lähde: Pohjoismaiden terveystilasto 2013 (Nomesko), s. 44, taulukko 3.1.1: Kooste itse ilmoitetusta liikalihavuudesta, 15-vuotiaat ja sitä vanhemmat asukkaat

Liikalihavuudella tarkoitetaan, että painoindeksi (BMI) on yli 30. Norjasta on huomioitu ikäryhmä $16+$

Esimerkiksi keuhkosyövän määrä miljoonaa asukasta kohti vaihtelee voimakkaasti eri maiden välillä. Vuonna 2011 Tanskassa oli runsaat 800 tapausta ja Ruotsissa vähän alle 400 .

Pohjoismaiden tulee tehdä päätös tiiviimmän kokemustenvaihdon käynnistämises- tä kansanterveysalalla, etenkin alkoholi- ja tupakkapolitiikan keinoista. Tavoitteena tulee olla alkoholin ja tupakan kulutuksen vähentäminen hyödyntämällä eri maiden kokemuksia. Maiden ja alueiden, joissa on alhaiset alkoholinoston ikärajat ja korkeat promillerajat liikenteessä, tulee saada tietoa muiden maiden kokemuksista. 


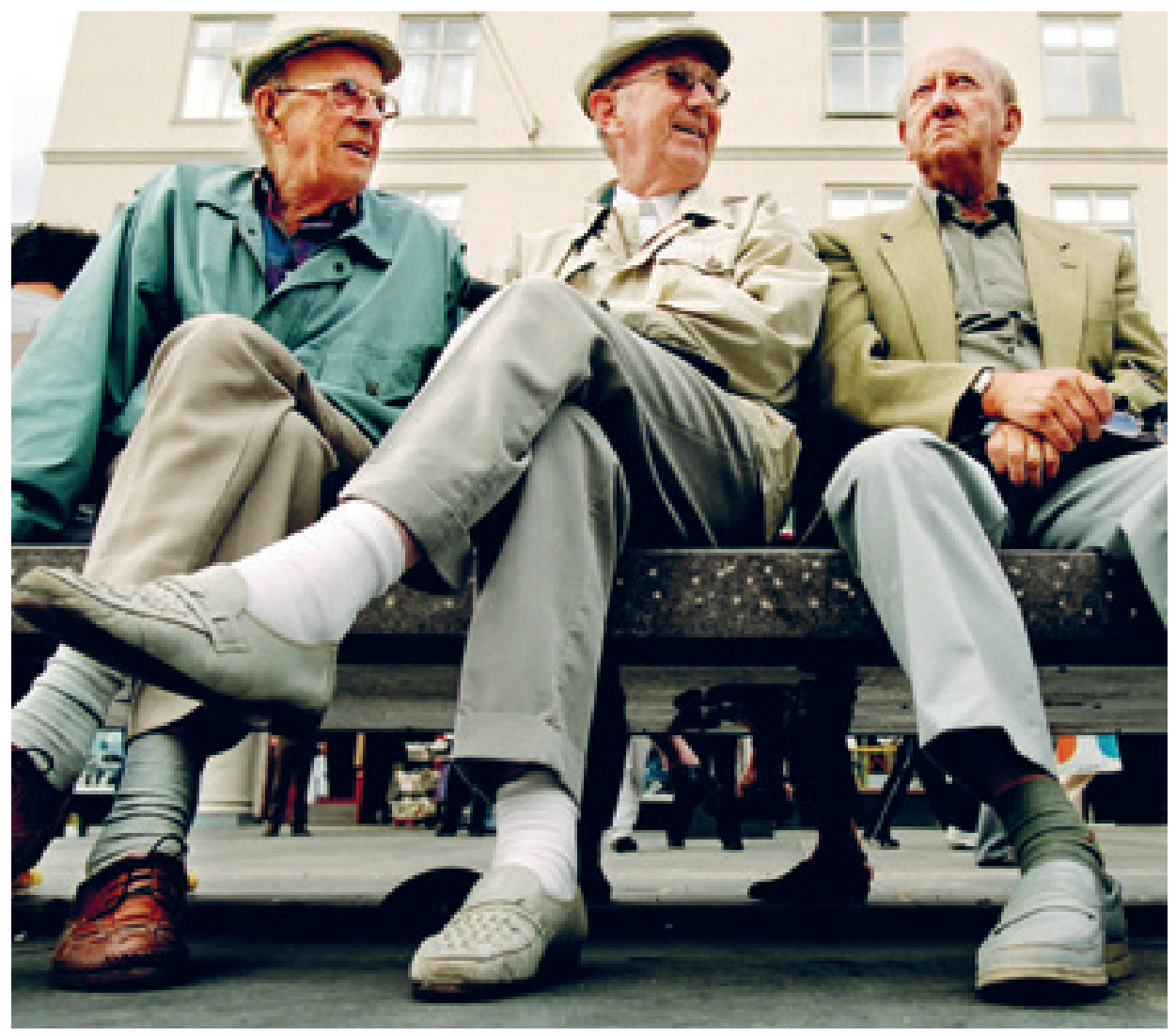

KAREN BEATE NøSTERUD/NORDEN.ORG

\section{Ehdotus 6 Pohjoismainen kansanterveyspolitiikan foorumi terveyden epätasaisen jakautumisen vähentämiseksi}

Perustetaan pohjoismainen kansanterveyspolitiikan foorumi, jonka tehtävänä on laatia ehdotuksia pohjoismaisiksi hankkeiksi ja toimiksi vähentämään terveyden epätasaista jakautumista.

Pohjoismaissa kansanterveys on kehittynyt myönteiseen suuntaan monen vuoden ajan. Pohjoismainen hyvinvointimalli, jolle on tyypillistä suhteellisen pienet erot taloudellisissa standardeissa, tarjoaa hyvät edellytykset terveyserojen kaventamiseen. Siitä huolimatta Pohjoismaissa on huomattavia terveyseroja korkeasti koulutettujen korkeatuloisten ja vähän koulutettujen pienituloisten välillä. Moninaiset elintavoista johtuvat krooniset sairaudet ovat suuri haaste pohjoismaiselle hyvin- voinnille. Parempi terveys tuottaa paljon hyötyä yhteiskunnalle: se pienentää sairastavuutta ja kuolleisuutta, parantaa elämänlaatua ja lisää hyvinvointia kaikkialla Pohjoismaissa. Sen vuoksi on korkea aika kääntää kasvavien terveyserojen suuntaus ta tehokkailla pohjoismaisilla toimilla.

Perustetaan pohjoismainen kansanterveyspolitiikan foorumi, joka saa tehtäväkseen laatia ehdotuksia pohjoismaisiksi hankkeiksi ja toimiksi terveyden epäta- 
saisen jakautumisen vähentämiseksi. Yhteistyötä täytyy keskittää ennen kaikkea ennalta ehkäiseviin toimiin ja tarkastella erilaisia elintapatekijöitä kuten alkoholia, tupakkaa, ruokavaliota, ravintoa ja liikuntaa. Uudeksi kansantaudiksi muodostuneen liikalihavuuden torjumiseksi voitaisiin esimerkiksi käynnistää kampanja. Ryhmällä täytyy myös olla valmiuksia tarttua Pohjoismaiden ministerineuvoston ehdottamiin kysymyksiin.
Foorumin osanottajiksi on hyvä valita poliitikkoja, käytännön työtä tekeviä, tutkijoita sekä virkamiehiä. Foorumin toiminnan tulee perustua monialaiseen näkökulmaan ja sen tulee tehdä yhteistyötä nykyisten pohjoismaisten työryhmien, verkostojen ja laitosten kanssa.

\section{Potilasliikkuvuus}

\section{Ehdotus $7 \quad$ Potilasliikkuvuus Pohjoismaissa}

\section{Pohjoismaat arvioivat ensi vuoden ministerikokoukseen mennessä, mitä vaikutuksia äskettäin hyväksytyn EU:n potilasdirektiivin täytäntöönpanolla on potilaille Pohjois- maissa ja pyrkivät edelleen laajentamaan potilaan oikeuk- sia saada hoitoa jossain toisessa Pohjoismaassa.}

Potilaille on luonnollisesti arvokasta, että he voivat valita hoidon tarjoajan. Tämä ei koske pelkästään omaa kuntaa ja omaa maata, vaan myös muita Pohjoismaita. On myös tärkeää, että hoitoa voi hakea ja tarvittaessa saada toisessa Euroopan maassa. EU on hyväksynyt potilasliikkuvuusdirektiivin, joka kattaa EU-maat sekä Norjan, Islannin ja Sveitsin.

Kaikki Pohjoismaat ovat hyväksyneet lakeja direktiivin täytäntöön panemiseksi. Lakien välillä on eroja.

Pohjoismailla on mahdollisuus sallia hieman suurempi valinnanvapaus Pohjois- maiden kansalaisille kunhan se ei johda muiden EU-kansalaisten osalta heikompaan tasoon kuin mitä EU-direktiivi määrää.

Direktiivin täytäntöönpanosta on kulunut vain muutama kuukausi, joten vielä ei voida arvioida sen vaikutuksia kansalaisten todelliseen valinnanvapauteen. Sen vuoksi ehdotetaan, että ministerit arvioivat vuoden kuluttua direktiivin täytäntöönpanosta, kuinka valinnanvapauden lisääminen on toteutunut. 


\section{Terveys ja teknologia}

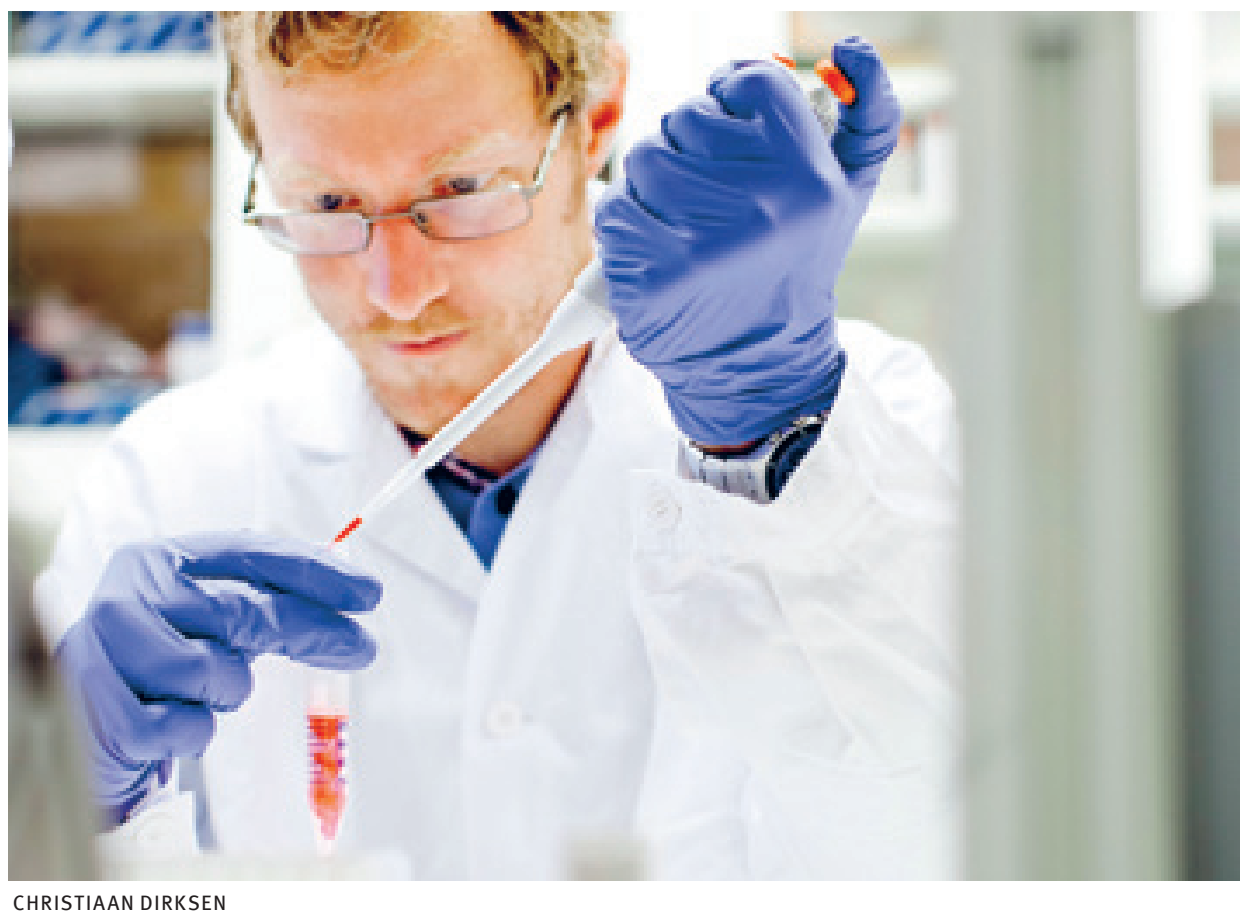

\section{Ehdotus 8 Lisätään yhteistyötä hyvinvointiteknologian alalla}

Pohjoismaat laativat yhteisen hyvinvointiteknologian määritelmän. Yhteispohjoismaisia markkinoita vahvistetaan yhtenäistämällä hyvinvointiteknologiatuotteiden standardeja ja laatimalla yhteisiä suuntaviivoja. Edistetään käyttäjien osallistamista hyvinvointiteknologian kehitystyöhön tiedonvälityksen, hyvien esimerkkien ja yhteisten suuntaviivojen avulla.

Hyvinvointiteknologiassa voi olla kysymys esimerkiksi osaamisesta ja tekniikan käytöstä, jotka parantavat toimintarajoitteisten henkilöiden, heidän omaistensa ja myös vanhusten turvallisuutta, toimintakykyä, osallistumista ja itsenäisyyttä. Laajemmin määriteltynä hyvinvointiteknologia tarkoittaa teknisiä ratkaisuja, jotka helpottavat paljon isompien kansalaisryhmien elämää ja lisäävät heidän osallistumismahdolli- suuksiaan. Muotoja on monia: hoito, apuvälineet, asumisratkaisut, kuntoutus, erityisopetus, esteettömät työpaikat tai yksilöllisesti sopeutettu viestintä. Esteetön suunnittelu on käsite, jonka avulla pyritään rakentamaan esteetöntä ja kestävää yhteiskuntaa kaikille. Työ on usein monialaista ja on tärkeää nähdä terveys- ja sosiaalisektori yhtenä kokonaisuutena. 


\section{Hyvinvointiteknologian pohjoismainen määritelmä}

Hyvinvointiteknologia on keskeisellä sijalla kaikissa Pohjoismaissa, mutta maat ovat valinneet hieman eri näkökulmia alaa koskevassa työssään. Pohjoismailla on viime vuosina ollut hyvinvointiteknologiaa koskevaa tiedon- ja kokemusten vaihtoa, ja yhteistyötä tehdään esimerkiksi innovaatioista ja niiden tehokkaammasta hyödyntämisestä. Pohjoismaiden ministerineuvosto on myös käynnistänyt kuntatasolla tehtävää pohjoismaista yhteistyötä kehittävän hankkeen. Edelleen puuttuu kuitenkin yhteinen ja yleisesti hyväksytty yhteispohjoismainen hyvinvointiteknologian määritelmä, joka helpottaisi työtä ja kohdentaisi sitä. Sen vuoksi ehdotetaan pohjoismaisen määritelmän laatimista.

\section{Yhteispohjoismaiset markkinat hyvinvointiteknologiatuotteiden standardeille}

Hyvinvointiteknologiatuotteiden kysyntä on ennätyksellisen korkealla ja alalle on syntynyt jo satoja uusia työpaikkoja. Uusien tuotteiden kehittämisessä tulisi kuitenkin pyrkiä yhtenäistämään alan pohjoismaisia markkinoita. Jos mailla olisi samanlaiset standardit uusille tuotteille, erityisesti kansainvälisesti vahvoilla aloilla, kysyntä ja volyymit olisivat suurempia alusta lähtien. Ruotsi johtaa tällä hetkellä esimerkiksi turvahälyttimien standardointia koskevaa yhteistyötä EU:ssa.

Hyvinvointiteknologian ratkaisut edellyttävät myös mitä suurimmassa määrin julkisen ja yksityisen sektorin välistä yhteistyötä. Sen vuoksi on tärkeää sisällyttää standardit julkisten hankintojen yhteydessä tarjousasiakirjoihin samalla tavalla kaikissa Pohjoismaissa. Pohjoismainen yhteistyö voi parhaimmillaan edistää näitä aloja Pohjoismaissa, mutta se tuottaa myös kilpailuetua globaaleilla markkinoilla. Sen vuoksi ehdotetaan, että hyvinvointiteknologiatuotteita koskevien standardien yhteispohjoismaisia markkinoita vahvistetaan.

\section{Käyttäjät tulee osallistaa hyvinvointi- teknologian kehittämiseen}

Toinen hyvinvointiteknologiassa huomioon otettava seikka on osallistaa työhön henkilöt, jotka itse käyttävät uusia teknisiä ratkaisuja. Uusi tekniikka liittyy usein läheisesti yksityiselämään uusien asumisratkaisujen ja yksilöllisesti sopeutetun tekniikan myötä. Eettisistä kysymyksistä on tärkeää keskustella avoimesti ja työstää henkilökohtaisia esteitä ja asenteita. Tämä koskee sekä uusien tekniikoiden käyttäjiä että niiden kehittäjiä. Pohjoismaat voivat näyttää esimerkkiä käyttäjien osallistamisessa kehitystyöhön. On tärkeää työskennellä paikallisesti, usein kuntatasolla, ja lisäksi tarvitaan kansallisen tason yhteistyötä. Pohjoismaisessa yhteistyössä voitaisiin keskittyä tiedonvälitykseen, parhaisiin käytäntöihin ja yhteispohjoismaisiin suuntaviivoihin käyttäjien osallistamisesta. 


\section{Ehdotus 9 Lisätään yhteistyötä eTerveyden alalla}

\section{Sähköisiä reseptejä koskevaa pohjoismaista yhteistyötä jatketaan. Perustetaan pohjoismainen verkossa toimiva terveyskirjasto. Luodaan pohjoismainen potilastietojen hakutyökalu lääkäreitä varten.}

eTerveydellä tarkoitetaan sähköisten prosessien ja sähköisen viestinnän avulla toteutettavaa hoitoa. Käsite voi kattaa joukon palveluita, kuten sähköiset potilaskertomukset, telelääketieteen ja potilaille annettavan terveystiedon. eTerveys tarkoittaa toiminnan kokonaisvaltaista uudistamista eikä pelkästään uusia teknisiä ratkaisuja.

\section{Sähköisiä reseptejä koskevaa pohjois-} maista yhteistyötä jatketaan

Pohjoismaat ovat osallistuneet aktiivisesti eTerveyttä koskevaan yhteistyöhön EU:ssa, esimerkiksi epSOS-hankkeeseen. Tavoitteena on ollut kehittää sähköisten reseptien eurooppalainen järjestelmä helpottamaan kansalaisten liikkumista rajojen yli lääkehoidosta riippumatta. EU:n hanke on päättynyt, mutta nyt on syytä jatkaa yhteistyötä Pohjoismaiden välillä. Pohjoismaiseen yhteistyöhön sisältyvät myös potilaskertomusten yhteiset rakenteet ja terminologia, eTerveyden kehitystyötä vertailevat ja mittaavat indikaattorit sekä rajat ylittävän toiminnan juridisten esteiden kartoittaminen.

\section{Yhteispohjoismainen verkossa toimiva terveyskirjasto}

Verkossa toimiva terveyskirjasto on suhteellisen uusi idea, jossa on päästy pisimmälle Norjassa. Kirjasto palvelee terveydenhuollon ammattilaisia ja sisältää hyviä esimerkkejä, hoitomenettelyohjeita, tietopankkeja ja aikakauslehtiä. Suurin osa sisällöstä on kuitenkin kaikkien kansalaisten saatavilla. Vastaavaa toimintaa on muissa maissa, mutta tarkoitus ja viitekehykset vaihtelevat. Yleinen suuntaus Pohjoismaissa on, että potilaiden tulee saada helpommin tietoa laadusta ja lääketieteellisistä tuloksista sekä voida käyttää suoraan kansalaisille suunnattua verkkopalvelua. Terveyskirjastoa koskeva yhteistyö olisi kustannustehokasta, toisi tieteellisen tiedon koko hoitohenkilöstön saataville ja lisäisi vielä kansalaisten tietoa ja vastuuta omasta terveydestään.

\section{Uusi pohjoismainen potilastietojen hakutyökalu lääkäreitä varten} Verkkokirjaston puitteissa voidaan myös kehitellä ajatusta potilastietojen hakutyökalusta. Kysymys on älykkäästä hakutoiminnosta, joka tarjoaa tukea lääkäreille potilaan hoitotarpeen yksilöllisessä arvioinnissa. Käytännössä järjestelmä toimisi siten, että lääkäri kirjoittaa potilaan oireet paljastamatta potilaan henkilöllisyyttä ja saa vastauksena tiedot muista samoista oireista kärsineistä potilaista sekä hoitoehdotuksia sisältävän ohjeen. Useimmat maat ovat kehittäneet potilaita ja hoitoa koskevan tiedonkeruun siten, että tällainen hakutyökalu olisi mahdollista kehittää. Tällainen hakutyökalu voisi parantaa potilasturvallisuutta ja siten lisätä luottamusta hoitoon. 


\title{
Psykiatria
}

\section{Ehdotus $10 \quad$ Vahvistetaan pohjoismaista psykiatrian alan yhteistyötä}

\author{
Pohjoismaista psykiatrian alan yhteistyötä vahvistetaan \\ vuosittain järjestettävällä psykiatrian alan huippukokouk- \\ sella ja lisäämällä pohjoismaista tiedonkeruuta ja koke- \\ musten vaihtoa parhaista käytännöistä.
}

\begin{abstract}
Mielenterveysongelmista aiheutuu usein suuria inhimillisiä seurauksia sekä yksilölle että hänen omaisilleen. Yhä useampi pohjoismaalainen saa diagnoosin psyykkisestä häiriöstä. Erityisesti tämä koskee lapsia ja nuoria, ja kyse on muista kuin psykoottisista häiriöistä. Mielenterveyshäiriöiden osuus koko sairaustaakasta on siis kasvamassa Pohjoismaissa, mikä vie paljon sosiaali- ja terveydenhuolIon resursseja. Mielenterveysongelmien ja psyykkisten häiriöiden lisääntymisellä on siten suuria yhteiskunnallisia seurauksia Pohjoismaille. Psyykkiset ongelmat ovat esimerkiksi merkittävä syy sairauspoissaoloihin, pitkäaikaistyöttömyyteen ja ennenaikaiseen eläköitymiseen.
\end{abstract}

Psyykkisistä syistä johtuneesta ennenaikaisesta eläkkeelle jäämisestä ei ole saatavilla järjestelmällisiä tilastoja Pohjoismaista, joten aihetta on syytä tarkastella lähemmin. Suomen kansaneläkelaitoksen vuonna 2009 tekemä tutkimus osoittaa kuitenkin, että viisi suomalaista nuorta jää päivittäin ennenaikaiselle eläkkeelle psyykkisen sairauden takia ja että lähes puolet kaikista Suomessa varhaiseläkkeelle jäävistä siirtyy eläkkeelle psyykkisen sairauden takia. Kaiken kaikkiaan kyse oli 117600 henkilöstä vuonna 2009. Puolet heistä jäi eläkkeen masennuksen takia. Vuosina 2004-2009 psyykkisen diagnoosin vuoksi ennenaikaiselle eläkkeelle jääneiden miesten osuus kasvoi $60,5 \%$ ja naisten osuus $42,1 \%$. Suurin kasvu oli alle 30 -vuotiaiden ryhmäs- sä. Samanlainen suuntaus on nähtävissä muissakin Pohjoismaissa, erityisesti alle 30-vuotiailla nuorilla.

Psyykkinen diagnoosi on myös ensisijainen syy siihen, että nuorelle henkilölle myönnetään jonkin tyyppinen ennenaikainen eläke. Näin on yli puolessa kaikista tapauksista Pohjoismaissa, noin $80 \%$ :ssa tapauksista Tanskassa ja 76 \%:ssa tapauksista Ruotsissa.

Pohjoismaiden hallitukset myöntävät, että on tarpeellista rinnastaa psykiatriset sairaudet fyysisiin sairauksiin. Kuluneina vuosina on tapahtunut huomattavaa kehitystä myös psykiatrian alan hoitotarjonnassa ja hoitomenetelmissä. Tärkeitä tekijöitä ovat muun muassa ennalta ehkäisevä työ, yhtenäisempi hoito ja potilaan itsensä osallistaminen, pakon vähentäminen, leimautumisen ehkäiseminen ja yksittäisen potilaan mahdollisuudet tervehtyä kokonaan tai osittain sairauden jälkeen. Nyt kiinnitetään myös enemmän huomiota terveyden epätasaiseen jakautumiseen, jota psyykkisistä häiriöistä kärsivät ihmiset kokevat. Heillä on nimittäin muuta väestöä suurempi todennäköisyys sairastua myös fyysisesti.

Psykiatria on samalla tieteenala, jolle on tyypillistä vähäinen tai puutteellinen tutkimustieto. Tutkimusta ja kehitystä on lisättävä, jotta psykiatrisen hoidon laatua pystytään todella parantamaan. Tutkimukseen perustuvia menetelmiä on kehitettävä ja niistä on levitettävä tietoa siten, että hoi- 
to perustuu suuremmassa määrin parhaaseen kulloinkin saatavilla olevaan tietoon.

Näiden haasteiden edessä ja ottaen huomioon yhteiskunnan rakennetta ja kehitystä leimaavat monet yhteiset piirteet Pohjoismaissa on itsestään selvää, että pohjoismaista psykiatrian alan yhteistyötä tulee vahvistaa siten, että maat voivat entistä paremmin hyötyä pohjoismaisten naapureidensa kokemuksista. Yhteistyössä tulee keskittyä seuraaviin asioihin:

- Lisätään kokemusten vaihtoa parhaiden käytäntöjen malleista siten, että yhden Pohjoismaan kokemuksista hyötyisivät muidenkin Pohjoismaiden asukkaat. Esimerkiksi uusia hoitomenetelmiä voitaisiin ottaa käyttöön sen jälkeen, kun niitä on testattu yhdessä Pohjoismaassa, tai uusia hoitomenetelmiä voitaisiin testata yhteistyössä.

- Lisätään tiedonkeruuta Pohjoismaissa laajentamalla tutkimusyhteistyötä sekä lisäämällä laadunmittaukseen ja laatumittareiden kehittämiseen liittyvää yhteistyötä. Psykiatrian alan laatumittauksia käsittelevässä yhteistyössä todettiin vuonna 2011, että Pohjoismailla on ainutlaatuiset mahdollisuudet laadun mittaamiseen muun muassa maiden toimivien laaturekisterien ansiosta. Tätä yhteistyötä kannattaa jatkaa ja vahvistaa.

- Järjestetään vuosittain psykiatrian alan huippukokous. Vuosittain järjestettävä psykiatrian alan huippukokous tulee olemaan kiistaton foorumi kokemusten vaihtoa sekä tiedon ja alan tulosten välittämistä ajatellen (ks. aiempi ehdotus). Psykiatrian alan huippukokous, johon osallistuu muun muassa päättäjiä, tutkijoita, käytännön työtä tekeviä ja käyttäjäjärjestöjä, voi samalla tuoda esiin psykiatrisista häiriöistä kärsivien ihmisten leimautumisen ongelmaa ja osaltaan auttaa vähentämään sitä. 


\title{
Terveydenhuollon valmius
}

\section{Ehdotus $11 \quad$ Laajennetaan terveydenhuollon valmiusyhteistyön toimeksiantoa}

\author{
Pohjoismaisesta valmiusyhteistyöstä vastaava ryhmä \\ (Svalbard-ryhmä) saa laajemman toimeksiannon, johon \\ sisällytetään kaikki terveydenhuollon valmiusyhteistyön \\ osa-alueet.
}

Pohjoismaiden terveysministerit allekirjoittivat puitesopimuksen terveydenhuollon valmiusyhteistyöstä kesäkuussa 2002. Sopimuksen tarkoituksena on kehittää ennakoivilla toimenpiteillä yhteispohjoismaista valmiutta ennalta ehkäistä ja hoitaa kriisejä ja katastrofeja. Epävirallinen työryhmä (Svalbard-ryhmä) sai tehtäväkseen yhteistyön kehittämisen. Sopimuksen piiriin kuuluvat perinteisten onnettomuuksien hoitamisen lisäksi erityisesti tapaukset, joissa mukana on biologisia ja kemiallisia aineita, radioaktiiviseen säteilyonnettomuuteen liittyvä erityisosaaminen ja terroristihyökkäykset.

Svalbard-ryhmän työ on osin toiminut erittäin hyvin, erityisesti verkostoyhteistyössä. Työryhmä on kuitenkin kohdannut tiettyjä vaikeuksia tehtäviensä hoidossa erityisesti siksi, että joka maassa asioita hoitavat monet eri viranomaiset ja laitokset, joiden näkökulmat ja tavoitteet poikkeavat toisistaan. Viime vuosina toiminnan painopiste on siirtynyt alkuperäisistä tehtävistä useisiin muihin katastrofeihin liittyviin tehtäviin, kuten ensihoitoon, ambulanssikuljetuksiin ja sairaanhoitopalveluihin.
On tärkeää laajentaa terveydenhuollon valmiutta siten, että se perustuu kattavaan turvallisuusnäkemykseen. Uusia uhkakuvia ilmestyy nopeaan tahtiin, erityisesti digitaalisen kehityksen vauhdittamana. Esimerkiksi erilaisiin kyberuhkiin varautuminen edellyttää tiiviistä eri alojen välistä yhteistyötä kansallisella, pohjoismaisella ja kansainvälisellä tasolla.

Toimeksiannon on lisäksi vastattava todellisuudessa tehtävää työtä. Viime aikoina kasvanut vakavien tapahtumien määrä vahvistaa tiiviimmän yhteistyön perusteita. On hyvin tärkeää, että vastuunjako on uudessa toimeksiannossa selkeästi määritelty Svalbard-ryhmän ja pohjoismaisten viranomaisten sekä laitosten kesken.

Terveydenhuollon valmiudessa yhteistyöhön voi sisältyä mm. yhteinen tutkimus- ja kehitystyö, koulutus, hankinnat ja varmuusvarastot. Konkreettisia esimerkkejä ovat yhteinen lentävän lääkintähenkilöstön koulutus ja yhteiset resurssit ilmateitse hoidettavalle lääkinnälliselle evakuoinnille. 


\section{Lääkkeet}

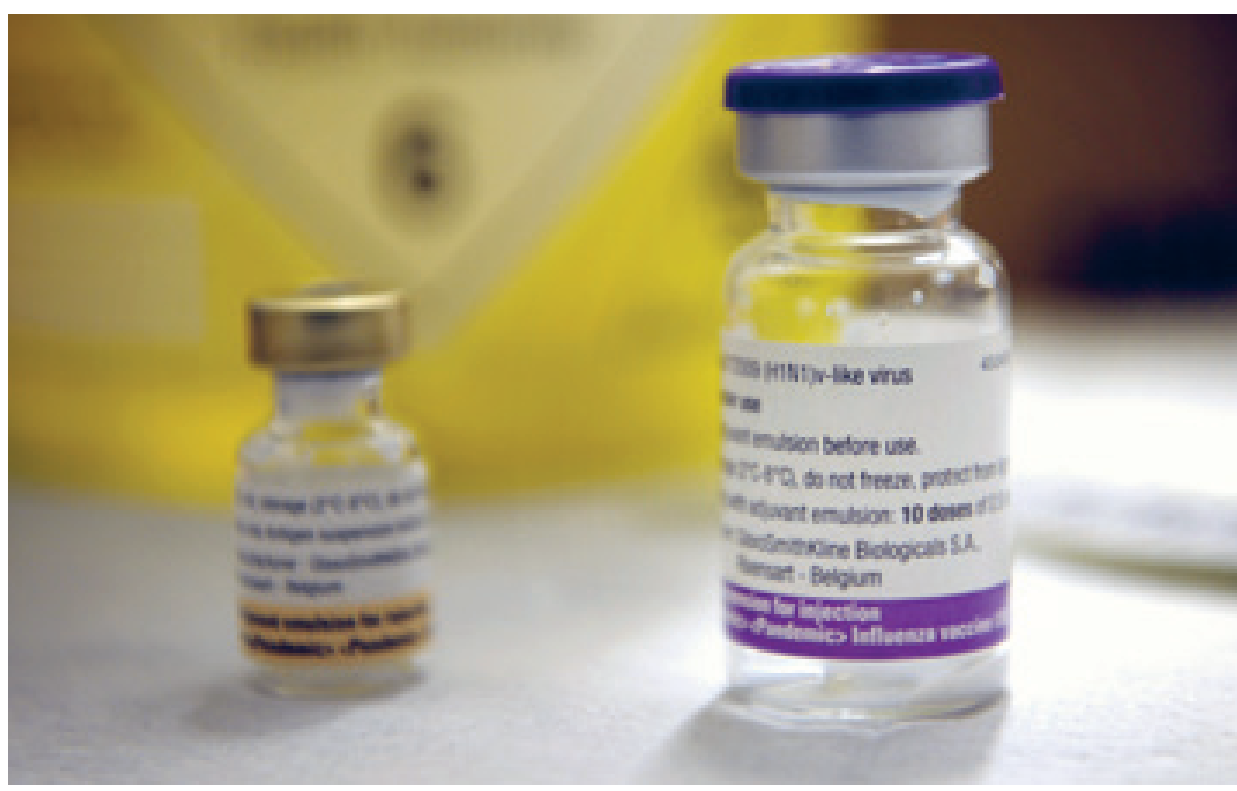

JOHANNES JANSSON/NORDEN.ORG

Ehdotus 12

\section{Laajennetaan pohjoismaista lääkealan yhteistyötä paremman kustannustehokkuuden ja turvallisuuden saamiseksi}

Pohjoismaista lääkealan yhteistyötä laajennetaan perustamalla yhteinen harvinaisten lääkkeiden lääkevarasto ja lisäämällä näihin lääkkeisiin liittyvää yhteistyötä sekä tiedonvaihtoa hankintasopimuksista ja uusien lääkkeiden käytöstä.

Lääkekulut muodostavat suuren osan maiden terveydenhuollon kustannuksista. Kaikki Pohjoismaat ovat OECD:n keskiarvon alapuolella, kun lääkekustannuksia tarkastellaan asukaskohtaisesti tai suhteessa BKT:hen. Vuonna 2011 OECD-maiden lääkekustannukset olivat keskimäärin kuudesosa maiden terveydenhuollon menoista, ja olivat näin ollen kolmanneksi suurin menoerä sairaalahoidon ja perusterveydenhuollon jälkeen.
Kuten kaikissa muissakin maissa, myös Pohjoismaissa on haasteena uusien ja usein hyvin kalliiden lääkkeiden tulo markkinoille, mistä potilaat usein hyötyvät huomattavasti mutta mikä luo paineita maiden terveydenhuollon kustannuksiin. Maantieteellisen läheisyyden ja kielellisen yhteyden ansiosta uusien lääkkeiden käytöstä on helppo saada tietoa naapurimaiden viestimistä, mikä saattaa aiheuttaa terveydenhoitoviranomaisille paineita seurata naapurimaiden päätöksiä. 
Maailman mittakaavassa yhden Pohjoismaan markkinat ovat liian pienet lääkevalmistajille - erityisesti tämä koskee harvinaisten sairauksien hoitoon tarkoitettuja lääkkeitä. Laajennetusta pohjoismaisesta yhteistyöstä onkin moneen otteeseen keskusteltu Pohjoismaiden ministerineuvostossa - muun muassa Islannin aloitteesta vuonna 2008 ja ministerikokouksessa Tanskan puheenjohtajakaudella vuonna 2010. Keskustelut eivät kuitenkaan ole johtaneet konkreettisiin tuloksiin johtuen siitä, että lääkealan järjestelmät poikkeavat toisistaan, mikä johtaa $\mathrm{mm}$. erilaiseen hinnoitteluun ja erilaisiin päätöksentekorakenteisiin.

On kuitenkin vielä mahdollista laajentaa pohjoismaista lääkealan yhteistyötä siten, että se hyödyttää Pohjoismaiden asukkaita. Tiedonvaihdon lisääminen ehdoista ja hinnoista, joita maat saavat hankintojen yhteydessä, vahvistaisi maiden neuvotteluasemaa jatkossa.

On myös tarpeen laajentaa tiedonvaihtoa uusien lääkkeiden käytöstä, mikä saat- taa myöhemmässä vaiheessa kehittyä varsinaiseksi, uusien lääkkeiden arviointia koskevaksi yhteistyöksi. Yhteistyötä ryhdytään tekemään maiden asianomaisten elinten kesken. Riippumatta yhteisten yleisten hankintojen tiellä olevista esteistä olisi myös tarkoituksenmukaista laajentaa yhteistyötä harvinaisten lääkkeiden tarvittavan valmiusvaraston ylläpitämiseksi. Kyse on Pohjoismaissa niin harvoin esiintyvistä sairauksista (esim. käärmeenpuremat, kurkkumätä, botulismi), ettei tehokkuuden nimissä ole järkevää perustaa omia kansallisia varastoja.

Yhteistyö voi aluksi johtaa harvinaisten lääkkeiden yhteispohjoismaisen lääkevaraston perustamiseen ja myöhemmin laajentua kattamaan valmiustuotteet eli rokotteet ja vastamyrkyt, joita harvoin tarvitaan, mutta joille on oltava valmiusvarasto kriisitilanteita varten (esim. rokkotautirokotteet). 


\section{Virkamiesvaihto}

\section{Ehdotus 13 Uusi pohjoismainen virkamiesvaihto - pilottihanke}

\section{Käynnistetään vahvistettu pohjoismainen virkamiesvaihto terveysalalla. Entistä useammalle ministeriön virkamiehel- le annetaan mahdollisuus lyhyeen virkamiesvaihtoon, jolla luodaan lisää ja parempia verkostoja edistämään pohjois- maista osaamista ja vahvistamaan kilpailukykyä.}

\begin{abstract}
Nykyinen pohjoismainen virkamiesvaihtosopimus on vuodelta 1979 ja se antaa valtion palveluksessa oleville mahdollisuuden tutustua hallintoon toisessa Pohjoismaassa, muka lukien Ahvenanmaa, Färsaaret ja Grönlanti, joko lyhyen tai pitemmän aikaa. Virkamiesvaihto on malliesimerkki pohjoismaisesta yhteistyöstä ja se on vuosien varrella saanut erittäin hyvää palautetta. Mainittakoon, että vaihdossa ei edellytetä keskinäistä työpaikanvaihtoa kahden virkamiehen kesken, ja että ohjelmaan osallistujat ovat palkallisella virkavapaalla. Vaihdon tarkoituksena on tutustua olosuhteisiin naapurimaissa, mikä syventää pohjoismaista yhteistyötä ja kehittää Pohjoismaiden julkisia laitoksia sekä virkamiesvaihtoon osallistujia myönteisellä tavalla.
\end{abstract}

Valitettavasti voidaan todeta, että virkamiesvaihtoon osallistutaan liian vähän. Osallistujia oli vain 47 vuonna 2013, ja heistä vain muutama oli ministeriöstä. Erityisesti eri viranomaiset lähettivät työntekijöitään naapurimaihin.

Jotta voitaisiin parantaa vastuuministeriöiden keskinäisen yhteydenpidon edel- lytyksiä, on ehdotettu lisäsopimusta nykyiseen virkamiesvaihtosopimukseen. Panostus olisi pilottihanke (3 vuotta), ja kohderyhmänä ovat terveysasioiden parissa asianomaisessa ministeriössä työskentelevät virkamiehet. Tavoitteena on luoda lisää ja parempia verkostoja asiaa hoitaviin ministeriöihin ja niiden välille Pohjoismaissa, jotta pohjoismainen osaaminen lisääntyisi ja kilpailukyky vahvistuisi. Siksi ehdotetaan lyhyitä, viikon tai kahden mittaisia virkamiesvaihtoja, joissa keskitytään verkostojen luomiseen ja siten parempaan tiedon ja kokemusten vaihtoon maiden välillä. Nykyisellään virkamiesvaihdon kesto on yhdestä kahteentoista kuukauteen, mikä saattaa muodostaa esteen monille työntekijöille ja heidän työnantajilleen.

Lyhyemmän oleskelun pitäisi tarjota osallistumismahdollisuus entistä useammalle virkamiehelle. Pilottihankkeen rahoituksen olisi tultava Pohjoismaiden ministerineuvoston budjetista. 


\title{
Kansalliset asiantuntijat EU:ssa
}
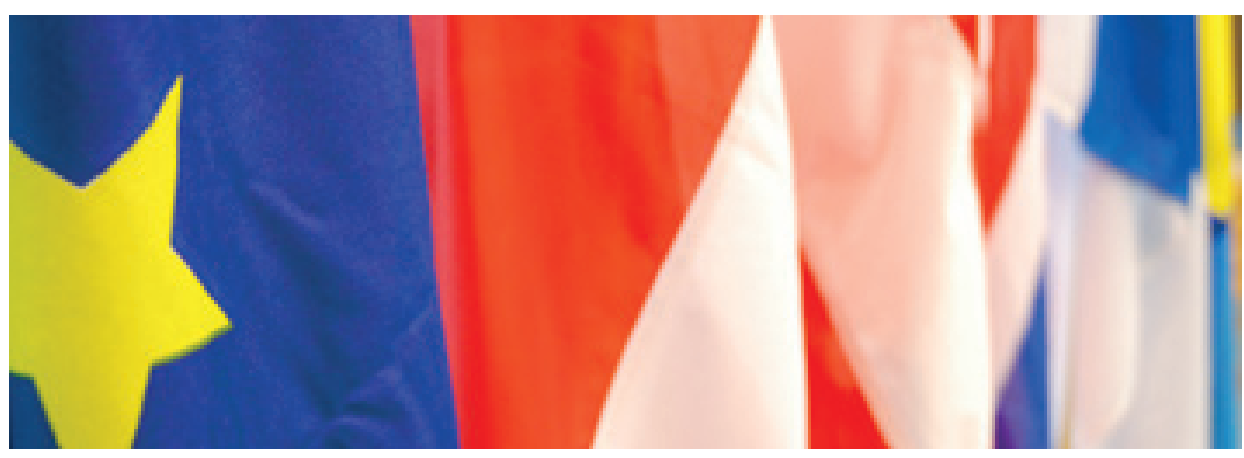

SILJE BERGUM KINSTEN/NORDEN.ORG

\section{Ehdotus 14}

\section{Pohjoismaista yhteistyötä kansallisten asiantuntijoiden sijoittamisessa Euroopan komissioon}

\author{
Sosiaali- ja terveysalalla käynnistetään uutta epävirallista \\ yhteistyötä kansallisten asiantuntijoiden sijoittamiseksi \\ Euroopan komissioon.
}

Pohjoismainen yhteistyö perustuu yhteisiin arvoihin, jotka muodostavat pohjoismaisen hyvinvointimallin perustan. Tätä nykyä hyvinvointivaltioon kohdistuu paineita erityisesti väestönkehityksen ja talouskriisin takia. Siksi maiden on toimittava yhdessä pystyäkseen vastaamaan näihin haasteisiin. Sen vuoksi ehdotetaan uutta pohjoismaista epävirallista yhteistyötä kansallisten sosiaali- ja terveysalan asiantuntijoiden lähettämiseksi Euroopan komission sosiaali- ja terveysalan pääosastoihin (DG EMPL ja DG SANCO).

Kaikki maat (myös Eta-maat) lähettävät asiantuntijoita EU:n toimielimiin. Tällä hetkellä esimerkiksi Ruotsilla on noin 30 asiantuntijaa, jotka työskentelevät kaikilla politiikan sektoreilla, eivät kuitenkaan sosiaali- ja terveysalalla.

Komissiossa olevan kansallisen asiantuntijan avulla voidaan vaikuttaa komissiossa käynnissä oleviin prosesseihin. Asiantuntija voi esimerkiksi vaikuttaa ehdotuksen muotoiluun, jakaa tietoa epävirallisesti ja olla sitä kautta huomattava resurssi kotimaalleen. Epävirallinen yhteistyö Pohjoismaiden kesken voisi saada aikaan parempaa ja tasaisempaa kansallisten asiantuntijoiden sijoittumista ja siten maiden resurssien parempaa hyödyntämistä. Olisi tehokkaampaa sijoittaa pohjoismaisia asiantuntijoita tasaisesti eri yksiköihin sen sijaan, että samassa yksikössä toimii useita asiantuntijoita, joilla on samat tai samankaltaiset näkemykset. Komissiossa työskentelevä kansallinen asiantuntija on suhteellisen suuri kuluerä ministeriölle, mikä rajoittaa maiden mahdollisuuksia vaikuttaa prosesseihin niiden alkuvaiheessa. Asiantuntijan palkan maksaa työnantaja (ministeriö tai viranomainen) ja kulukorvauksen EU:n toimielin (päivärahat ja matkakorvaukset virkapaikalle ja takaisin). 
Ensimmäinen vaihe uudessa yhteistyössä voisi olla Pohjoismaiden ministerineuvoston sosiaali- ja terveyspolitiikan virkamieskomitealle (ÄK-S) tiedottaminen kunkin maan kansallisista asiantuntijoista, jotka työskentelevät komissiossa. Sen jälkeen
Pohjoismaiden sosiaali- ja terveysministeriöiden kansainvälisten sihteeristöjen tulee kokoontua säännöllisesti keskustelemaan epävirallisen yhteistyön suunnittelusta. 
Pohjoismaiden ministerineuvosto

Ved Stranden 18

DK-1061 København K

www.norden.org

\section{Terveysalan pohjoismainen yhteistyö tulevaisuudessa}

Bo Könberg on laatinut riippumattoman raportin terveysalan pohjoismaisesta yhteistyöstä. Raportti sisältää konkreettisia ehdotuksia pohjoismaisen yhteistyön kehittämiseksi ja vahvistamiseksi seuraavien 5-10 vuoden aikana. Raportti esiteltiin Pohjoismaiden sosiaali- ja terveysministereiden kokouksessa Islannissa 11. kesäkuuta 2014.

Bo Könberg on ruotsalainen liberaali poliitikko, joka toimi Ruotsin sairaanhoito- ja sosiaalivakuutusministerinä vuosina 1991-1994. Hän johti tuolloin Ruotsin eläkeuudistustyötä. Hän on osallistunut useisiin hyvinvointialan selvityksiin Ruotsissa, muun muassa ÄDEL-uudistukseen sekä hoitomaksuselvitykseen.

Raportti sisältyy Pohjoismaiden ministerineuvoston kestävän pohjoismaisen hyvinvoinnin ohjelmaan, joka ministerineuvoston suurimpia panostuksia vuosina 2013-2015. www.norden.org/hyvinvointi 